\title{
Process Modeling of Direct Coal-Biomass to Liquids (CBTL) Plants with Shale Gas Utilization and $\mathrm{CO}_{2}$ Capture and Storage (CCS)
}

\author{
Yuan Jiang, Debangsu Bhattacharyya*
}

Department of Chemical Engineering, West Virginia University, Morgantown, WV 26505, USA

\begin{abstract}
Direct coal liquefaction (DCL) technologies have been commercially demonstrated for producing transportation fuels from non-petroleum sources. However, significant amount of hydrogen is required in the DCL process due to the low $\mathrm{H} / \mathrm{C}$ ratio in coal. As a result, DCL processes are usually associated with a high level $\mathrm{CO}_{2}$ emission from hydrogen production units. Hence, direct coal biomass to liquids (CBTL) processes with $\mathrm{CO}_{2}$ capture and storage (CCS) and shale gas utilization are proposed in this work as an option for reducing $\mathrm{CO}_{2}$ emission. In this study, the focus is on process simulation and calculation of material and energy balances of novel direct CBTL plants, which can be used as a basis for further studies, such as optimization, techno-economic analysis and life-cycle analysis. In this process, coal with moderate amount of biomass is converted into syncrude through reaction with the hydrogen-donor solvent and gaseous hydrogen in a catalytic two-stage liquefaction unit. Hydrogen required for the liquefaction and product upgrading unit is produced from the liquefaction residue partial oxidation unit and the shale gas steam reforming unit or from the coal/biomass/residue co-gasification unit. Different CCS technologies are evaluated to achieve $90 \%$ overall carbon capture if high extent of $\mathrm{CO}_{2}$ capture is considered. Results of individual plant sections are validated with the existing data, if available. Sensitivity studies have been conducted to analyze the effects of key operating parameters and design parameters, such as the sources of hydrogen, CCS technologies, extent of CCS, and biomass/coal ratio. Key measures studied in this work include the fuel yield, thermal efficiency, CCS penalty and $\mathrm{CO}_{2}$ emission.
\end{abstract}

\section{Key Words}

Coal, Biomass, Shale gas, Direct liquefaction, $\mathrm{CO}_{2}$ capture and storage

\footnotetext{
* Corresponding author.

Tel:1-304-293-9335, E-mail: Debangsu.Bhattacharyya@ mail.wvu.edu
} 


\section{Introduction}

Due to the worldwide insecurity of crude oil supply, and volatile crude oil price, studies on production of liquid fuels from coal are being conducted especially in those countries that have lack of petroleum resources but abundant coal reserves. Indirect coal liquefaction (ICL) and direct coal liquefaction (DCL) technologies have already been commercialized. In the ICL process, coal is first sent to the gasification unit to be converted into syngas [1]. Then the clean syngas from the acid gas removal unit is sent to the Fischer-Tropsch reactor to be converted into syncrude [2-5]. The Fischer-Tropsch technology is the key of the ICL process, which is first introduced in 1920s, and still under commercial operation in South Africa [6]. In the DCL technology, coal is converted to liquid by adding hydrogen at high pressure and temperature. Various DCL technologies have been developed in last hundred years such as Solvent Refined Coal (SRC)-I and SRC-II, Exxon Donor Solvent (EDS), H-Coal and catalytic two-stage liquefaction (CTSL) [7-10]. One big issue with both the ICL and DCL processes is the high life-cycle greenhouse gas (GHG) emissions. Adding biomass and/or shale gas into the feedstock and applying carbon capture and storage (CCS) are possible solutions to the GHG emission problem [5,9,11-15]. Therefore, locations with adequate coal, biomass and shale gas resources, such as the Appalachian region, are potential candidates for siting these plants $[16,17]$.

Even though the DCL technology is claimed to have higher thermal efficiency than the ICL technology [1], most published studies on the process systems analysis, including process synthesis, optimization, and economic analysis, of coal liquefaction processes have focused on the ICL technology, mainly because the ICL technology is more mature and has adequate industrial experience [18-20]. In the area of the DCL technology, the focus in the existing literature is on design and optimization of liquefaction reactor and separation system individually rather than process systems analysis. Instead of the earlier single-stage liquefaction reactors, the two-stage liquefaction technology has been developed to achieve higher solid conversion and liquid yield as well as lower heteroatom content and hydrogen consumption $[7,8]$. In the two-stage technology, operating conditions in two reactors in series are optimized for coal dissolution in the first-stage and hydrotreating/hydrocracking in the second stage [8]. The Shenhua DCL plant in Inner Mongolia, China, which is the only operating commercial scale DCL plant after World War II, has been developed based on the NEDOL process developed in Japan and the CTSL process developed by the Hydrocarbon Technologies Inc. (HTI) in the United States [9]. Other than that, the Residual Oil Supercritical Extraction-Solids Rejection (ROSE-SR) process can be combined with the traditional vacuum distillation technology to increase the oil recovery in the separation system with lower utility consumption leading to higher process efficiency [21,22]. Separation of ash and unreacted coal from heavy liquids is difficult because of the small size of solid particles, the small difference in densities 
between solids and liquids, and the high viscosity and melting point of the liquids. In the ROSE-SR unit, benzene, toluene, xylene or their mixtures can be used as a solvent near their critical temperature and pressure because of their high solubility for direct liquefaction liquids [23]. The ROSE-SR process can recover $85-93 \%$ of the solvent as a supercritical fluid in the second stage settler saving about $40-50 \%$ of the utility in comparison to evaporation-based processes [22]. Furthermore, partial oxidation (POX) of liquefaction residues, an ash containing carbonaceous solid, can be used for producing hydrogen and reducing the need for external hydrogen requirement [24-26]. Since 1970's, Texaco Inc. has conducted a series of studies on the suitability of using coal liquefaction residues as feedstocks to entrained flow gasifiers where the liquefaction residues were fed into the gasifier as a molten fluid or water slurry $[27,28]$.

Despite several efforts to increase the process efficiency of the DCL processes, the life cycle GHG emission for producing the DCL liquids is about double of that for producing them from the petroleum source [7]. In order to convert coal $(\mathrm{H} / \mathrm{C} \approx 0.8)$ to transportation fuels $(\mathrm{H} / \mathrm{C} \geq 1.8)$, either carbon needs to be rejected in the form of $\mathrm{CO}_{2}$ (as in the ICL technology) or hydrogen needs to be added from external sources (as in the DCL technology) [2-4,6,7]. In DCL plants, the $\mathrm{H} / \mathrm{C}$ ratio is increased by adding gaseous hydrogen to a slurry mixture of coal and recycled coal-derived liquids, so-called H-donor solvent, at high temperature and pressure in presence of catalysts. Coal gasification has been used in the Shenhua DCL plant for producing make-up hydrogen because of the relatively low cost and sufficient supply of coal in China. Mixtures of coal, biomass, and liquefaction residues can also be converted to syngas by cogasification (CG) $[2,12,29]$. If natural gas or shale gas is available locally with reasonable price, hydrogen can also be produced by steam methane reforming (SMR) with less GHG emission in comparison to coal gasification [1,14]. Even though the conventional feedstock for the SMR unit is natural gas, due to abundant and cheap shale gas that is now available in the United States, shale gas is a potential feedstock in the SMR unit. However, because of the higher ethane and propane content in the shale gas in comparison to the natural gas, an adiabatic pre-reformer is preferred to convert ethane and propane before the main steam reforming reactor to prevent coke formation on reformer walls and catalyst surfaces [3032]. It has been reported that current commercial hydrogen production technologies, either gasification or SMR, are usually associated with a large amount of $\mathrm{CO}_{2}$ emission. A recent study shows that about 0.48 tonne of $\mathrm{CO}_{2}$ is released per barrel of transportation fuels produced in the Shenhua DCL plant, where about $80 \%$ of that $\mathrm{CO}_{2}$ is produced in the gasification-based hydrogen production unit [7]. In order to reduce GHG emissions, a small amount of biomass can be co-fed with the coal to the direct liquefaction reactors [33-35]. CCS technologies can also be applied in order to further reduce the overall carbon footprint of the liquefaction processes. [15] 
Biomass is considered to be a carbon-neutral feedstock, because the $\mathrm{CO}_{2}$ released to the atmosphere is reutilized by biomass. [13] Several experimental studies have been conducted on coal-biomass coliquefaction [8,11,34-36]. Some researchers have reported that co-liquefaction of biomass and coal under mild condition (about $350^{\circ} \mathrm{C}$ ) has higher conversion and oil yield than those that would be predicted based on a simple linear combination of the conversion and oil yield of liquefaction of biomass and coal independently [11,37]. This could be a result of the difference in the thermal cleavage temperature between coal and biomass. Biomass has a higher conversion and lower thermal cleavage temperature than coal, and can produce free radicals at lower temperature to promote the reaction of coal [36]. However, the synergistic effect reduces with the increasing temperature and pressure, as the reactivity of coal increases [36,38]. Ai performed a series of preliminary studies on co-processing of Shenhua coal and Sawdust at $450^{\circ} \mathrm{C}$, which is similar to the operating conditions in the commercial DCL reactors, and observed that presence of sawdust resulted in apparent improvement of coal conversion [39]. Their study also shows that because of the higher $\mathrm{H} / \mathrm{C}$ ratio of biomass compared to that of coal, the hydrogen consumption in the direct liquefaction plant and $\mathrm{CO}_{2}$ emission associated with hydrogen production can be reduced by increasing the biomass content in the system [39]. Even though several efforts have been made to understand the kinetics and thermal behavior of DCL reactions and the hydrodynamics of DCL reactors [40-43], the direct coal-biomass to liquids (CBTL) process has been hardly modeled in details at the equipment-level or at the system-level especially with a focus on reduction of GHG emission from this process. Process modeling and simulation of the liquefaction section and the hydrogen production section simultaneously can help to accurately estimate the throughput of the hydrogen production section and associated $\mathrm{CO}_{2}$ emission with different types and ratios of coal, biomass and shale gas. This would, in turn, help to obtain a more accurate estimate of the thermal efficiency and operating and capital costs of the CCS technologies for a given level of $\mathrm{CO}_{2}$ capture.

As mentioned before, significant amount of $\mathrm{CO}_{2}$ is generated for producing $\mathrm{H}_{2}$ irrespective of whether the gasification or SMR route is used. The $\mathrm{CO}_{2}$ present in the product stream from these processes has to be removed to produce high-purity hydrogen even if CCS is not considered. Additional $\mathrm{CO}_{2}$ might need to be captured if high extent of CCS is considered. In most commercial plants, $\mathrm{CO}_{2}$ is typically captured by physical or chemical absorption. [39] In the chemical absorption processes, the main utility consumption is in the reboiler of the solvent stripper. In the physical absorption process, the solvent can be simply regenerated by pressure swing or thermal regeneration of only a portion of the solvent, but solvent chilling may be necessary leading to significant utility consumption. The selection of the appropriate technology mainly depends on the $\mathrm{CO}_{2}$ partial pressure $\left(\mathrm{C}_{\mathrm{CO}_{2}}\right)$, extent of $\mathrm{CO}_{2}$ capture and other components present in the stream. If $P_{\mathrm{CO}_{2}}$ is high enough to provide sufficient driving force and 
concentration of hydrocarbons (or other components with high solubility in physical solvents) are low, physical absorption is preferred because it is typically more energy-efficient than the chemical absorption and the captured $\mathrm{CO}_{2}$ is released at relatively high pressure (HP) resulting in lower power consumption in the downstream $\mathrm{CO}_{2}$ compressor. [44] Otherwise, chemical absorption is preferred for $\mathrm{CO}_{2}$ removal. In chemical absorption, $\mathrm{CO}_{2}$ is typically released at low pressure (LP) adding to the cost of compression, because the stripper pressure is limited by the solvent decomposition temperature [45]. For example, the physical absorption technologies (i.e. Selexol, Rectisol) are preferred for pre-combustion $\mathrm{CO}_{2}$ capture from the syngas generated by coal gasification mainly because of high $P_{\mathrm{CO}_{2}}$ and lack of hydrocarbons, while chemical absorption technologies (i.e. MEA, MDEA) are preferred for the post-combustion $\mathrm{CO}_{2}$ capture from the low pressure flue gas [46-48]. Even though, large number of studies have been conducted on selection of CCS technologies for different $\mathrm{CO}_{2}$-producing technologies, such as the Fischer-Tropsch technology [20,47], integrated gasification combined cycle [46,48], pulverized coal combustion and natural gas combined cycle [46], not much studies have been conducted on selection of technologies for CCS in the direct liquefaction technology.

To summarize, the existing literature lacks systems level analysis of the DCL process that can greatly benefit from the cheap and abundant shale gas (especially in the continental US) and biomass as well as the novel CCS technologies due to potential improvement in its thermal efficiency, fuel yield, and environmental performance. With this motivation, four novel plant configurations are proposed and plantwide models are developed for these configurations. The configurations are SMR_CCS (base case), SMR_VT, CG_CCS, and CG_VT, where the first acronym before the underscore denotes whether hydrogen is produced from shale gas steam methane reforming (SMR) or coal/biomass/residue cogasification (CG), while the second acronym denotes whether $\mathrm{CO}_{2}$ is stored (CCS) or vented (VT). Our focus in this paper is on process synthesis, technology selection and performance analysis, which provides the basis for further studies, such as optimization, life cycle analysis, and techno-economic analysis [1]. In particular, contributions of this work can be summarized as follows:

(1) proposed four novel configurations for direct CBTL processes and developed high-fidelity plant-wide models for each of them, (2) utilized shale gas as a novel sources for $\mathrm{H}_{2}$ in the direct CBTL process, (3) designed the CCS units for all configurations, (4) investigated the plant performance in terms of productivity, efficiency and $\mathrm{CO}_{2}$ emission for different hydrogen sources, CCS solvent, extent of CCS and biomass to coal ratio, and (5) compared the direct CBTL plant with indirect CBTL plant for various process configurations.

\section{Process design and modeling}


Block flow diagrams (BFD) of direct CBTL plants are shown in Fig. 1 and Fig. 2. Liquefaction technology is the core technology for all different configurations. Coal and biomass with a low biomass/coal ratio (8/92 weight basis, base case) are mixed with the recycled oil in the slurry tank, and then pressurized and preheated before being fed to CTSL reactors along with make-up and recycled $\mathrm{H}_{2}$. The product from the second liquefaction reactor is sent to a hot HP separator. The vapor product from the hot HP separator is then sent to the inline hydrotreater for stabilization. Hydrotreated liquids from the inline hydrotreater and the liquid product from the hot separator are sent to the hydrocarbon recovery and solid/liquid separation unit to be separated into $\mathrm{H}_{2}$-rich gases, light gases $\left(\mathrm{C}_{1}-\mathrm{C}_{4}\right)$, light naphtha $\left(\mathrm{C}_{5}, \mathrm{C}_{6}\right)$, heavy naphtha $\left(\mathrm{C}_{7}-177^{\circ} \mathrm{C}\right)$, distillate/gas oil $\left(177-376^{\circ} \mathrm{C}\right)$, solvent oil $\left(376-524^{\circ} \mathrm{C}\right)$ and liquefaction residues (more than $524^{\circ} \mathrm{C}$ ). $\mathrm{H}_{2}$-rich gases and solvent oil are recycled back to the CTSL unit. A portion of the light gases is used in the process furnaces, while the remaining is sent to the power island for electricity generation. Naphtha and gas oil are sent to the product upgrading unit for generating on-spec gasoline and diesel as main products. The liquefaction residue is sent to the POX unit for $\mathrm{H}_{2}$ production.

Because considerable amount of $\mathrm{H}_{2}$ is consumed in the CTSL unit, hydrogen production is also critical for direct CBTL plants. Considering different $\mathrm{H}_{2}$ sources and $\mathrm{CO}_{2}$ control targets, four different configurations are considered in our study. In the SMR_CCS (base case) and SMR_VT processes as shown in Fig. 1, a portion of the required $\mathrm{H}_{2}$ is generated from partial oxidation of the liquefaction residue, while the remaining is generated by shale gas steam reforming. Alternatively, the required $\mathrm{H}_{2}$ is supplied from coal/biomass/liquefaction residue co-gasification. In the CG_CCS and CG_VT processes as shown in Fig. 2, pre-processed coal and biomass are fed to the liquefaction unit and the POX unit along with liquefaction residues, while other blocks remain the same as the SMR_CCS and SMR_VT processes. In all configurations, the syngas from the POX/CG unit and/or the SMR unit is sent to the acid gas removal (AGR) unit for $\mathrm{CO}_{2}$ and $\mathrm{H}_{2} \mathrm{~S}$ removal, and then to pressure swing adsorption (PSA) unit for $\mathrm{H}_{2}$ purification. Three different $\mathrm{CO}_{2}$ capture technologies are considered for the AGR unit- Selexol, monoethanolamine (MEA), piperazine- activated methyl diethanolamine (MDEA/PZ). $\mathrm{H}_{2} \mathrm{~S}$ produced in the POX/CG unit via gasification is removed in the $\mathrm{H}_{2} \mathrm{~S}$ absorber of the dual-stage Selexol unit, while $\mathrm{H}_{2} \mathrm{~S}$ produced in the liquefaction and hydrotreating units is removed by chemical absorption using MDEA as solvent. The removed $\mathrm{H}_{2} \mathrm{~S}$ is then sent to the Claus unit to be recovered as elemental sulfur. In the SMR_VT and CG_VT processes, $\mathrm{CO}_{2}$ captured from the syngas is directly vented to the atmosphere. In the SMR_CCS and CG_CCS processes considering high extent of CCS, a portion of the flue gas produced from the gas turbine or process furnaces also needs to be sent to the AGR unit for postcombustion $\mathrm{CO}_{2}$ removal, and all $\mathrm{CO}_{2}$ streams from the AGR unit are sent to the $\mathrm{CO}_{2}$ compression section for sequestration. 


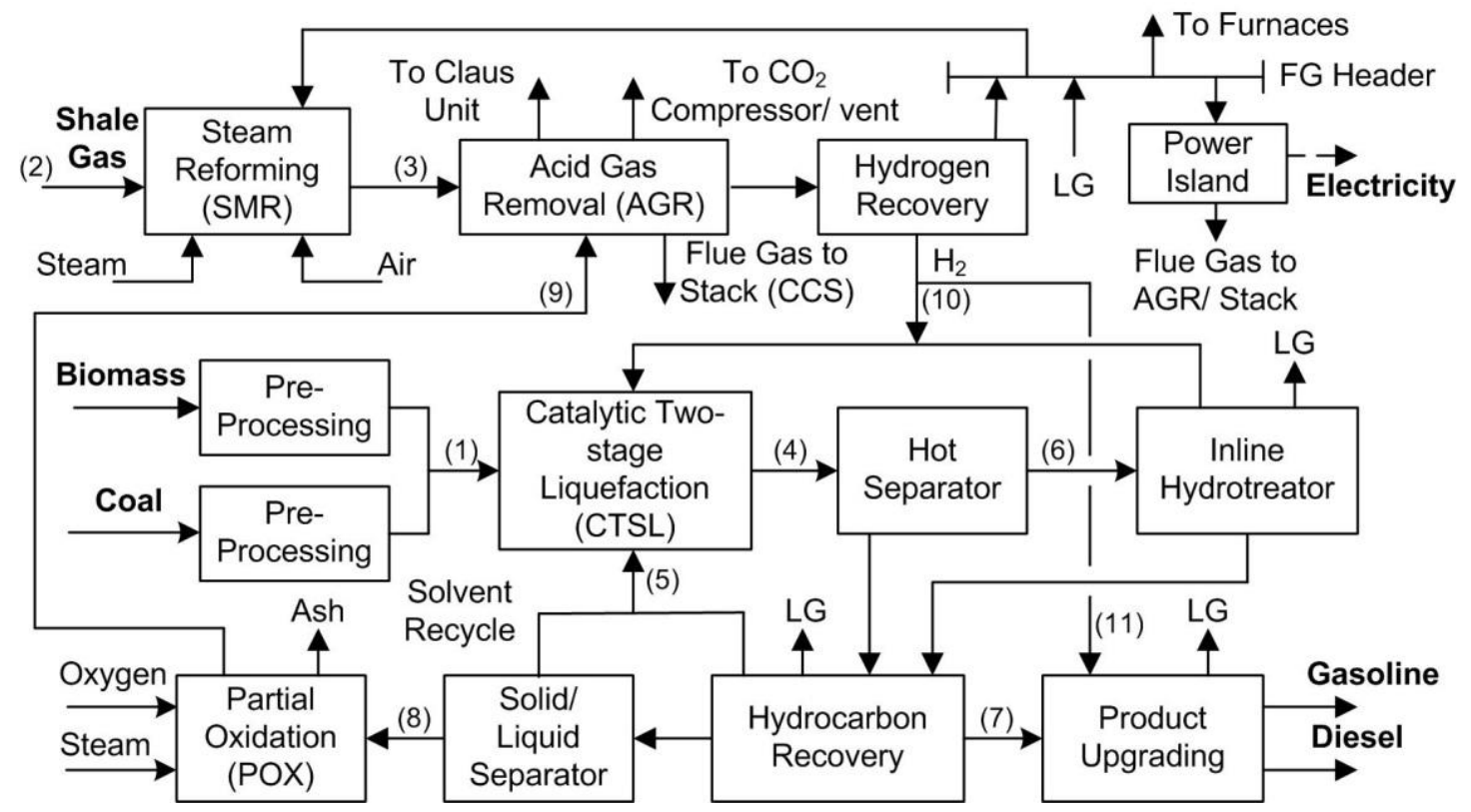

Fig. 1. BFD of the direct CBTL plant with $\mathrm{H}_{2}$ from shale gas (SMR_CCS/SMR_VT).

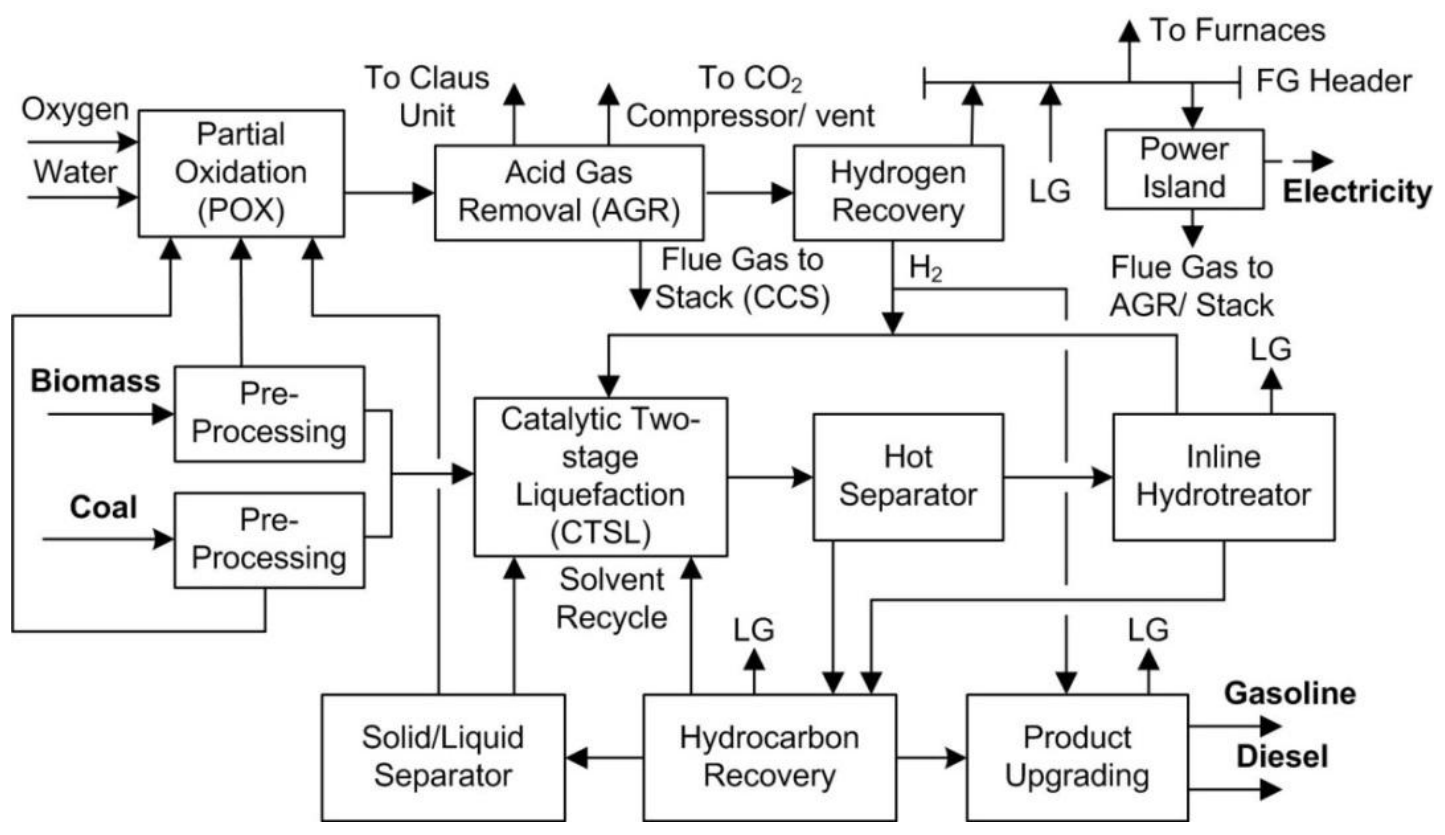

Fig. 2. BFD of the direct CBTL plant with $\mathrm{H}_{2}$ from coal and biomass (CG_CCS/CG_VT).

\subsection{Steady-state modeling approach}

In this section, the steady-state modeling approach of the direct CBTL plants is discussed. The plant is divided into five well-defined sections - the liquefaction and product recovery section, the product upgrading section, the syngas production section, the acid gas removal and hydrogen recovery section, 
and the combined cycle power island. Most of the unit operations are modeled as standard equipment items in Aspen Plus, while yield models are developed in Excel for liquefaction reactors and upgrading units based on the experimental or operational data available in the open literature. Aspen User2 blocks are used to connect Excel with Aspen Plus. In the process model, coal and biomass are specified as unconventional component, while syncrude are specified as either pseudo-components or petroleum assays defined by boiling point ranges. The compositions of Illinois No.6 coal, wood chip and Marcellus shale gas are given in Table 1 and Table 2 [48-50].

For all case studies, hydrogen, carbon and utility balances have to be satisfied and constrained by Eq. (1) to (3). In the liquefaction plant, $\mathrm{H}_{2}$ is consumed due to liquefaction and hydrotreating while it is produced from gasification, steam reforming and catalytic reforming. The make-up $\mathrm{H}_{2}$ requirement and purge rate of $\mathrm{H}_{2}$-rich recycle stream from the liquefaction and hydrotreating units are determined by the required $\mathrm{H}_{2}$ partial pressure $\left(P_{\mathrm{H}_{2}}\right)$ and $\mathrm{H}_{2} /$ solid or $\mathrm{H}_{2} /$ oil ratio. Feed flowrates of shale gas and coal/biomass mixture to the syngas production section are determined by the hydrogen balance, as shown in Eq. (1). The entire gas oil column bottom produced in the product upgrading unit and a portion of the fuel gas (FG) produced in the entire plant are utilized as heating utilities in the furnaces. Eq. (2) is used to determine the percentage of the remaining fuel sent to the power island based on the utility balance. Eq. (3) is used to determine the amount of $\mathrm{CO}_{2}$ to be captured.

$H_{2, \text { produced from SMR,POX,catalytic reforming }}=H_{2, \text { consumed in liquefaction, hydrotreating }}$

$\frac{F G \times L H V_{F G}+\text { Gas oil } \times L H V_{\text {Gas oil }}-Q_{\text {Process funances }}}{L H V_{F G}}=F G$ to gas turbine

$\frac{\text { Carbon in products }+ \text { Carbon in captured } \mathrm{CO}_{2}}{\text { Total Carbon in the feedstock }}=$ Extent of CCS $(90 \%$, base case $)$

\section{Table 1}

Proximate and ultimate analysis of coal and biomass feedstock.

\begin{tabular}{lcccccccccc}
\hline & Proximate analysis (dry basis) & \multicolumn{8}{c}{ Ultimate analysis (dry basis) } \\
& $\mathrm{M}$ & $\mathrm{FC}$ & $\mathrm{VM}$ & $\mathrm{A}$ & $\mathrm{A}$ & $\mathrm{C}$ & $\mathrm{H}$ & $\mathrm{N}$ & $\mathrm{S}$ & $\mathrm{O}$ \\
\hline Coal & 3.08 & 50.65 & 37.85 & 11.50 & 11.50 & 71.00 & 4.80 & 1.40 & 3.20 & 8.00 \\
Biomass & 9.58 & 16.55 & 82.51 & 0.94 & 0.94 & 48.51 & 6.17 & 0.12 & 0.04 & 44.22 \\
\hline
\end{tabular}

\section{Table 2}

Composition of Marcellus shale gas (well 3). 


\begin{tabular}{lccccc}
\hline Component & $\mathrm{C}_{1}$ & $\mathrm{C}_{2}$ & $\mathrm{C}_{3}$ & $\mathrm{CO}_{2}$ & $\mathrm{~N}_{2}$ \\
\hline vol\% & 83.8 & 12.0 & 3.0 & 0.9 & 0.2 \\
\hline
\end{tabular}

\subsection{Liquefaction and product recovery}

\subsubsection{Catalytic two-stage liquefaction (CTSL) unit}

In the CTSL unit, coal and biomass are mixed with hot recycle solvents in the slurry tank, preheated and then sent to two ebullated bed reactors in a close-coupled mode with recycled and make-up $\mathrm{H}_{2}$ stream. [51-53] Because the heavy oil produced from the $2^{\text {nd }}$ stage is recycled to form feed slurry and is fed back to the $1^{\text {st }}$ stage, two stages are interrelated and treated as a single unit in this study [54]. A yield model is developed for the CTSL unit fed with coal and small amount of biomass. As mentioned in Section 1, biomass can promote DCL process under mild condition, while the synergistic effect gets reduced with the increasing temperature being comparatively negligible under the normal operating temperature of the DCL reactors [11,36-39]. Hence, in this study the interaction between coal and biomass is ignored because of the low percentage of biomass in the feedstock and high operating temperature and pressure, and therefore the yield of the coal biomass co-liquefaction reaction is considered to be a linear combination of the yields from the coal and biomass liquefaction reactions. The yield of liquids and their hydrocarbon distribution from the coal liquefaction reactors are estimated based on the operating data from the DCL proof-of-concept (POC) facility reported by HTI in 1995 [21]. Operating conditions in POC-01 Period 26, shown in Table 3, were recommended by HTI's study because of its higher efficiency and better operability, and therefore, are considered in our baseline study [21,51]. There is limited information in the open literature on direct biomass liquefaction using oil as the slurry medium and $\mathrm{H}_{2}$ as the reduction gas. In this work, data from the Pittsburgh Energy Research Center (PERC) are used as baseline. In the process reported by the PERC, wood chips were fed to the reactor with the recycle oil serving as the solvent. The oil yield was about $45-55 \%$ of the dry wood with about $100 \%$ conversion of the wood [55-57]. It is also assumed that the elimination of oxygen from wood can occur by producing $\mathrm{H}_{2} \mathrm{O}, \mathrm{CO}$ and $\mathrm{CO}_{2}$ [58]. Therefore, the yield of bio-oil and gases can be estimated by atom balance with the elemental analysis of bio-oil to be $81 \mathrm{wt} \%$ carbon, $10.2 \mathrm{wt} \%$ hydrogen and $8.8 \mathrm{wt} \%$ of oxygen as reported in the open literature [56,59]. These assumptions result in an estimated oil yield of $47 \%$ from the biomass liquefaction, which is consistent with the experimental data [56]. In order to simplify atom balance calculation in the yield model of coal/biomass co-liquefaction, syncrude is specified as pseudocomponents in Aspen Plus, with the elemental composition of each crude cut calculated by a linear combination of the corresponding data of coal liquids reported by HTI and biomass liquids reported by PERC $[21,56,59]$. The yield model of the coal-biomass co-liquefaction process is developed in MS Excel 
by applying atom balance for calculating $\mathrm{H}_{2}$ consumption and the yield of gases (i.e. $\mathrm{CO}, \mathrm{CO}_{2}, \mathrm{NH}_{3}, \mathrm{H}_{2} \mathrm{~S}$, $\mathrm{H}_{2} \mathrm{O}$ ), since the heteroatoms in the coal and biomass are either converted into gases or contained in the liquids. For the base case with a biomass/coal weight ratio of 8/92, the calculated elemental composition of syncrude and the results from the reactor model are shown in Table 4 and Table 5.

Table 3

Operating conditions of the CTSL unit.

\begin{tabular}{lclc}
\hline Variable & Value & Variable & Value \\
\hline Reactor inlet pressure $(\mathrm{MPa})$ & 22.1 & $1^{\text {st }}$ stage temperature $\left({ }^{\circ} \mathrm{C}\right)$ & 407 \\
Reactor outlet pressure $(\mathrm{MPa})$ & 20.7 & $2^{\text {nd }}$ stage temperature $\left({ }^{\circ} \mathrm{C}\right)$ & 432 \\
Hydrogen partial pressure $\left(P_{\mathrm{H}_{2}}, \mathrm{MPa}\right)$ & 13.4 & Solvent/feed ratio $(\mathrm{wt} / \mathrm{wt})$ & 1.82 \\
\hline
\end{tabular}

\section{Table 4}

Element analysis of raw syncrude (base case).

\begin{tabular}{lccccccc}
\hline \multirow{2}{*}{ Crude cut } & \multirow{2}{*}{$\begin{array}{c}\text { Average } \\
\text { NBP }\left({ }^{\circ} \mathrm{C}\right)\end{array}$} & \multirow{2}{*}{$\begin{array}{c}\text { Specific } \\
\text { gravity }\end{array}$} & \multicolumn{5}{c}{ Elemental composition (wt\%) } \\
\cline { 5 - 8 } & 93 & 0.799 & 84.75 & 14.09 & 0.99 & 0.16 & 0.01 \\
\hline IBP-177 ${ }^{\circ} \mathrm{C}$ & 93 & & $\mathrm{H}$ & $\mathrm{O}$ & $\mathrm{N}$ & $\mathrm{S}$ \\
$177-288^{\circ} \mathrm{C}$ & 232 & 0.924 & 86.92 & 11.33 & 1.54 & 0.20 & 0.02 \\
$288-3444^{\circ} \mathrm{C}$ & 315 & 0.975 & 87.89 & 10.05 & 1.84 & 0.20 & 0.02 \\
$344-454^{\circ} \mathrm{C}$ & 399 & 1.012 & 88.63 & 9.93 & 1.17 & 0.21 & 0.04 \\
$454-\mathrm{FBP}$ & 540 & 1.097 & 88.78 & 8.11 & 1.10 & 0.52 & 1.45 \\
\hline
\end{tabular}

Table 5

Outlet stream distribution of the coal/biomass CSTL reactors (base case).

\begin{tabular}{lllllc}
\hline Component & wt\% & Component & wt\% & Component & wt $\%$ \\
\hline Coal & 1.14 & $\mathrm{C}_{1}$ & 0.57 & $288-344{ }^{\circ} \mathrm{C}$ & 8.86 \\
$\mathrm{H}_{2} \mathrm{O}$ & 4.06 & $\mathrm{C}_{2}$ & 0.45 & $344-454{ }^{\circ} \mathrm{C}$ & 45.92 \\
$\mathrm{H}_{2} \mathrm{~S}$ & 0.94 & $\mathrm{C}_{3}$ & 0.47 & $454{ }^{\circ} \mathrm{C}-\mathrm{FBP}$ & 17.36 \\
$\mathrm{CO}$ & 0.18 & $\mathrm{C}_{4}$ & 0.76 & $\mathrm{Char}$ & 0.03 \\
$\mathrm{CO}_{2}$ & 0.69 & $\mathrm{IBP}-177^{\circ} \mathrm{C}$ & 5.57 & Ash & 3.45 \\
$\mathrm{NH}_{3}$ & 0.43 & $177-288^{\circ} \mathrm{C}$ & 9.1 & & \\
\hline
\end{tabular}

\subsubsection{Product recovery and inline hydrotreating}

As shown in Fig. 3, the product from the CTSL reactors is first sent to the hot HP separator. The vapor product from the hot HP separator, consisting of $\mathrm{H}_{2}$-rich light gases, most of the naphtha $\left(\mathrm{IBP}-177^{\circ} \mathrm{C}\right)$ and 
a portion of the gas oil and solvent oil $\left(177-454^{\circ} \mathrm{C}\right)$, is then sent to the inline hydrotreater for stabilization. The hydrotreated syncrude is sent to warm and cold HP flash vessels. The vapor product from the cold HP flash separation contains about $80-85 \% \mathrm{H}_{2}$ and therefore most of this $\mathrm{H}_{2}$-rich stream is recycled back to the liquefaction reactor, while a portion of it is purged to maintain the $P_{\mathrm{H}_{2}}$ in liquefaction reactors. Liquid products from the warm and cold HP flash vessels are sent to the warm and cold LP flash vessels, respectively. The bottom product from the hot HP separator is de-pressurized and sent to the LP reactor liquid flash vessel where small amount of $\mathrm{N}_{2}$ is used for stripping. The top product from the LP reactor liquid flash vessel is sent to the warm LP flash vessel while the top product from the warm LP flash vessel is sent to the cold LP flash vessel. Liquid products from the warm and cold LP flash vessels, mainly IBP- $454^{\circ} \mathrm{C}$ syncrude, are sent to the atmospheric distillation column to be separated into light gases, light naphtha, heavy naphtha, gas oil, and liquefaction solvent. The bottom product from the LP reactor liquid flash vessel, a mixture of heavy oil and solid residues, is sent to the vacuum distillation column and the ROSE-SR unit for solid/liquid separation. The bottom product from the atmospheric distillation column, heavy vacuum gas oil (HVGO) from the vacuum distillation column and the deashed oil (DAO) from the ROSE-SR unit are sent to the recycle solvent tank for preparing coal/biomass slurry. Light naphtha, heavy naphtha, and gas oil from the atmospheric distillation column and light vacuum gas oil (LVGO) from the vacuum distillation column are sent to product upgrading units to produce gasoline, diesel and gas oil column bottom.

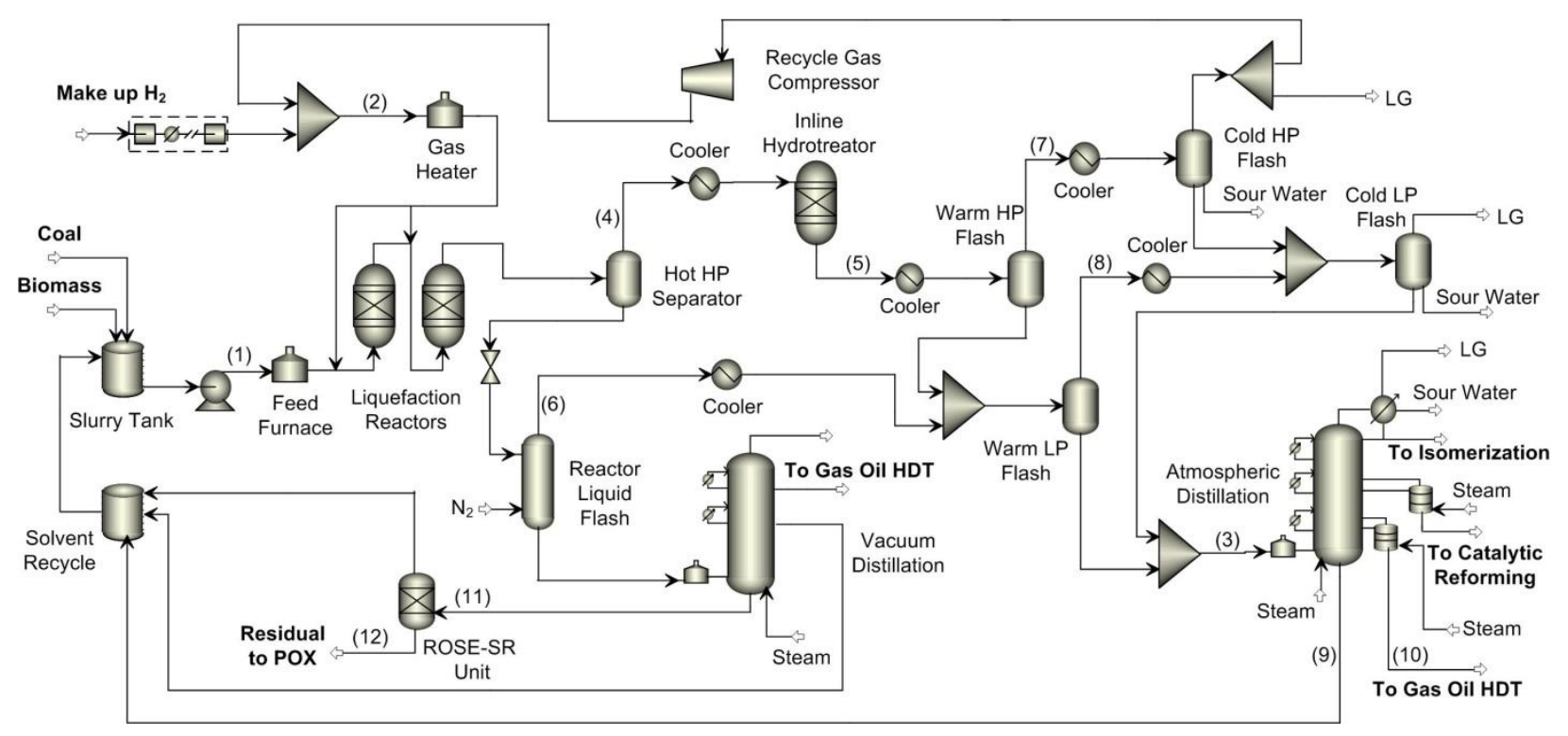

Fig. 3. Plant configuration of the liquefaction and product recovery section.

The plant configuration of the ROSE-SR unit can be found in Fig. 4. The deashing solvent, which is considered to be mainly toluene in our study, is mixed with the hot stream from vacuum column bottom 
and then fed into the $1^{\text {st }}$ stage settler with a solvent to vacuum column bottom weight ratio of 3 [60, 61]. The heavy phase from the $1^{\text {st }}$ stage settler, containing 10-20 wt $\%$ of the liquefaction liquids along with deashing solvent and essentially all of the solids, is "let down" to the deashing solvent separator operated at atmospheric pressure [22,61]. The light phase from the $1^{\text {st }}$ stage settler, which contains $80-90 \mathrm{wt} \%$ of the liquefaction liquids and deashing solvent, is heated and sent to the $2^{\text {nd }}$ stage settler. In the $2^{\text {nd }}$ stage settler, most of the solvent is recovered under supercritical condition as the decrease in density and solubility of the supercritical fluid with the increasing temperature is exploited for solvent separation in the $2^{\text {nd }}$ stage settler. The light phase from the $2^{\text {nd }}$ stage settler, containing mainly supercritical solvent, is cooled in a heat exchanger and then sent to the HP solvent tank for preparing recycle solvent. The heavy phase from the $2^{\text {nd }}$ stage, containing mainly deashed oil and small amount of deasing solvent, is "let down" to another deashing solvent separator. A small portion of the deashing solvent is recovered from the two deashing solvent separators, which is cooled and condensed and sent to the deashing solvent feed tank and then pumped to the HP solvent tank. The DAO is recycled to the liquefaction reactor serving as $\mathrm{H}$-donor solvent and is hydrocracked to improve the performance of liquefaction unit, while the residues is partially oxidized to syngas and shifted to hydrogen in order to reduce the external hydrogen demand of the whole liquefaction system. More information about the POX unit is provided in Section 2.4.2.

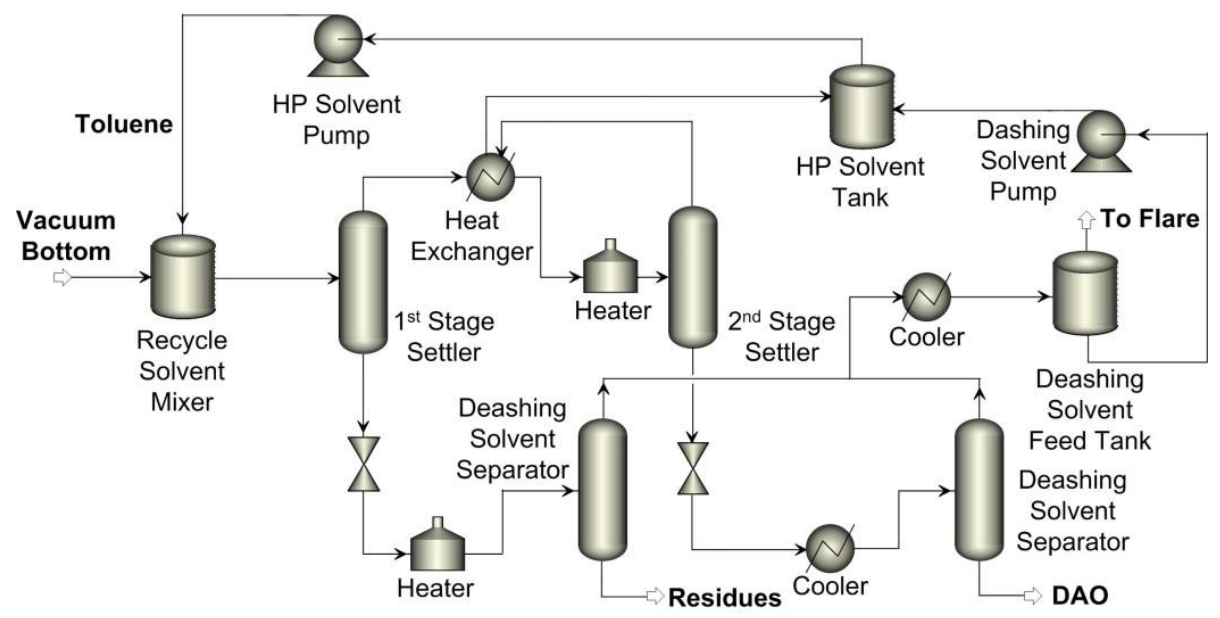

Fig. 4. Plant configuration of the ROSE-SR unit.

The approach to modeling the inline hydrotreater is the same as the liquefaction reactor [3]. With the elemental analysis of raw syncrude calculated from Section 2.2.1 and known elemental analysis of hydrotreated syncrude reported by HTI [21,51], the $\mathrm{H}_{2}$ consumption of the inline hydrotreater is estimated by atom balance, assuming $\mathrm{O}, \mathrm{N}$ and $\mathrm{S}$ in the syncrude are rejected by producing $\mathrm{H}_{2} \mathrm{O}, \mathrm{H}_{2} \mathrm{~S}$ and $\mathrm{NH}_{3}$. Table 6 lists the elemental analysis of the hydrotreated syncrude obtained from the open literature. [21,51]. For the inline hydrotreater, the syncrude is specified as pseudo-components for the sake of 
applying atom balance, while syncrude is specified as petroleum assay for other equipment items in the product recovery unit for better estimate of vapor-liquid equilibrium (VLE). For each cut specified in Table 4 and Table 6, true boiling point distillation curves are available in the open literature $[21,56]$. Peng-Robinson equation of state (EOS) is used as the thermodynamic model for the system [62]. Both atmospheric and vacuum distillation columns are modeled using PetroFrac block in Aspen Plus. The $1^{\text {st }}$ stage and $2^{\text {nd }}$ stage settlers in the ROSE-SR unit are modeled as component separators, using solids rejection efficiency and energy balance reported by HTI and assuming $88 \%$ and $80 \%$ solvent recovery in the light phases from the $1^{\text {st }}$ and $2^{\text {nd }}$ stage settlers, respectively [21,63]. Deashing solvent separators are modeled as flash separators. Table 7 and Table 8 summarize the operating conditions and design specifications of the key equipment items in the product recovery unit. Detailed specifications of the distillation columns can be found in the Appendix A.

\section{Table 6}

Elemental analysis of hydrotreated syncrude.

\begin{tabular}{lccccc}
\hline wt $\%$ & $\mathrm{C}$ & $\mathrm{H}$ & $\mathrm{O}$ & $\mathrm{N}$ & $\mathrm{S}$ \\
\hline $\mathrm{IBP}-177{ }^{\circ} \mathrm{C}$ & 85.54 & 14.05 & 0.01 & 0.01 & 0.00 \\
$177-288^{\circ} \mathrm{C}$ & 87.90 & 12.55 & 0.01 & 0.01 & 0.01 \\
$288-344^{\circ} \mathrm{C}$ & 88.30 & 11.97 & 0.01 & 0.02 & 0.01 \\
$344-454^{\circ} \mathrm{C}$ & 88.10 & 11.28 & 0.01 & 0.03 & 0.05 \\
\hline
\end{tabular}

Table 7

Operating conditions of the product recovery unit.

\begin{tabular}{lcclcc}
\hline Equipment & $\begin{array}{c}\text { Pressure }^{(1)} \\
(\text { bar })\end{array}$ & $\begin{array}{c}\text { Temperature }^{(2)} \\
\left({ }^{\circ} \mathrm{C}\right)\end{array}$ & Equipment & $\begin{array}{c}\text { Pressure } \\
(\text { bar })\end{array}$ & $\begin{array}{c}\text { Temperature } \\
\left({ }^{\circ} \mathrm{C}\right)\end{array}$ \\
\hline Warm HP flash drum & 172 & 232 & Cold HP flash drum & 170 & 40 \\
LP reactor liquid flash drum & 7.9 & 405 & Warm LP flash drum & 7.8 & 232 \\
Atmospheric distillation & 2.8 & $40 / 320$ & Cold LP flash drum & 7.6 & 40 \\
tower & 0.1 & $65 / 305$ & $1^{\text {st }}$ stage settler & 55 & 300 \\
Vacuum distillation tower & 1.0 & $325 / 270$ & $2^{\text {nd }}$ stage settler & 54.5 & 370 \\
Deashing solvent separator & & & & & \\
\hline
\end{tabular}

(1) Top pressure for all towers

(2) Top/bottom temperature for all towers

\section{Table 8}

Design specifications of the product recovery unit. 


\begin{tabular}{|c|c|c|c|}
\hline Equipment & Manipulated variable & Target & Value \\
\hline Hot HP separator & Operating temperature & $\begin{array}{l}\text { ASTM D86 FBP of the vapor } \\
\text { product }\end{array}$ & $370{ }^{\circ} \mathrm{C}$ \\
\hline LP reactor liquid flash drum & Stripping $\mathrm{N}_{2}$ flowrate & $\begin{array}{l}\text { Recovery of the } 288-344^{\circ} \mathrm{C} \\
\text { syncrude in vapor }\end{array}$ & $50 \%$ \\
\hline \multirow[t]{3}{*}{$\begin{array}{l}\text { Atmospheric distillation } \\
\text { tower }\end{array}$} & $\begin{array}{l}\text { Bottom flow rate of heavy } \\
\text { naphtha stripper }\end{array}$ & $\begin{array}{l}\text { ASTM D86 95vol\% } \\
\text { temperature of light naphtha }\end{array}$ & $107{ }^{\circ} \mathrm{C}$ \\
\hline & $\begin{array}{l}\text { Bottom flow rate of } \\
\text { distillate stripper }\end{array}$ & $\begin{array}{l}\text { ASTM D } 8695 \mathrm{vol} \% \\
\text { temperature of heavy naphtha }\end{array}$ & $187^{\circ} \mathrm{C}$ \\
\hline & $\begin{array}{l}\text { Bottom flow rate of main } \\
\text { column }\end{array}$ & $\begin{array}{l}\text { ASTM D86 95vol } \% \\
\text { temperature of gas oil }\end{array}$ & $376^{\circ} \mathrm{C}$ \\
\hline \multirow[t]{3}{*}{ Vacuum distillation tower } & Duty of top pump-around & First stage temperature & $65^{\circ} \mathrm{C}$ \\
\hline & $\begin{array}{l}\text { Sidestream flow rate of } \\
\text { LVGO }\end{array}$ & $\begin{array}{l}\text { ASTM D86 95vol\% } \\
\text { temperature of LVGO }\end{array}$ & $376^{\circ} \mathrm{C}$ \\
\hline & $\begin{array}{l}\text { Sidestream flow rate of } \\
\text { HVGO }\end{array}$ & $\begin{array}{l}\text { Recovery of } 890-975^{\circ} \mathrm{F} \text { crude } \\
\text { in bottom }\end{array}$ & $77.3 \%$ \\
\hline \multirow[t]{2}{*}{ ROSE-SR unit } & $\begin{array}{l}\text { Operating temperature of } \\
\text { deashing solvent separators }\end{array}$ & $\begin{array}{l}\text { Solvent recovery of deashing } \\
\text { solvent separators }\end{array}$ & $98 \%$ \\
\hline & $\begin{array}{l}\text { Heat duty of the heat } \\
\text { exchanger between settlers }\end{array}$ & $\begin{array}{l}\text { Inlet temperature of the first } \\
\text { stage settler }\end{array}$ & $300{ }^{\circ} \mathrm{C}$ \\
\hline
\end{tabular}

\subsubsection{Heat integration in the liquefaction and product recovery section}

In the direct CBTL plant, the coal/biomass slurry and recycled $\mathrm{H}_{2}$ need to be pre-heated to a high temperature before being fed to the CTSL reactors, which results a considerable fuel consumption in the pre-heating furnaces. The product from the liquefaction reactor has to be cooled for separation. In the DCL baseline design reported by Bechtel/Amoco [51], the recycle $\mathrm{H}_{2}$ is pre-heated by exchanging heat with the hot stream from the top of the hot and warm HP flash vessels. Even though exchange of heat between cold slurry feed and downstream fluid is not considered by Bechtel/Amoco, it is considered to reduce the duty of the preheat furnaces in the SRC-I, SRC-II and NEDOL processes [64-66]. In this study, a global heat integration analysis is considered for increasing the overall thermal efficiency. Aspen Energy Analyzer is used to design and optimize the heat exchanger network. The minimum temperature approach is set to be $10{ }^{\circ} \mathrm{C}$. The forbidden matches between streams are specified to avoid operability problem such as that caused by large differential pressure and unexpected leakage during operation.

\subsection{Product upgrading}

One advantage of DCL process is that the products can be processed similar to traditional petroleum products without extensive renewal of current infrastructures [7]. Compared with typical petroleum oils, the DCL syncrude obtained from the two-stage liquefaction of bituminous coals is usually low in boiling range, low in hydrogen and high in oxygen, low in heteroatom contents and high in contents of cyclic compounds, and mainly composed of paraffins, naphthenes, and aromatics [7,9,67]. On the other hand, 
bio-liquids usually contain high amount of oxygenates, such as cyclic ketones, alkyl-phenols, methoxyphenols, napthols, which can be converted to cyclohexane, alkyl-cyclohexane by hydrotreating $[55,56,59]$. Despite these differences, the syncrude produced in the direct liquefaction plant with low biomass/coal ratio is very similar to petroleum and can be processed through petroleum refining technologies, where hydroprocessing is a major technology [68].

In this study, a significant portion of the aromatics and heteroatom in the low boiling range oil is converted in the inline hydrotreating unit. The hydrotreated naphtha cut from the atmospheric distillation column is low in sulfur and nitrogen and has an octane number of about 70, which is an excellent feed for gasoline production [21]. Isomerization and catalytic reforming technologies are applied to increase the octane number of this naphtha cut. Because the entire gas oil cut from the CTSL reactors is not sent to the inline hydrotreater considering the operating flexibility and product quality [68], the gas oil recovered from the atmospheric distillation column needs to be sent to the gas oil hydrotreating unit for further upgrading. In this study, the yields of the upgrading units are obtained from correlations due to the limited information on the detailed feed composition. Utility consumptions in the isomerization and catalytic reforming units are estimated based on the plant throughput using the correlations available from Bechtel Corp. [69], while detailed models of the key equipment items are developed to estimate the utility consumption in the gas oil hydrotreating unit, as shown in Fig. 5.

In the isomerization unit, n-paraffins in the light straight run naphtha with low octane number are transformed on Pt catalyst into branched chains with the same carbon number but high octane number. The typical yield of isomerization unit used in this study is $0.35 \mathrm{wt} \% \mathrm{C}_{3}, 2.39 \mathrm{wt} \% \mathrm{C}_{4}$ and $97.26 \mathrm{wt} \% \mathrm{C}_{5+}$ with a research octane number ( $\mathrm{RON}$ ) of 83 [62]. The $\mathrm{H}_{2} /$ oil ratio in the feed is specified to be $0.14 \mathrm{wt} \%$ as reported by Bechtel Corp. [69]. Our study only considers low biomass/coal mix ratio, and most of the oxygenates is hydrotreated and converted to paraffins and naphthenes in the hydrotreater unit. Hence, the distribution of components in the hydrotreated naphtha from biomass/coal co-liquefaction is assumed to be 15 vol\% paraffins, 65 vol\% naphthenes and 20 vol\% aromatics, which are similar to that of DCL naphtha [7,9,51]. A yield model, shown in Eq. (4) and (5), is used in this study to estimate the yield of $\mathrm{H}_{2}$ and $\mathrm{C}_{5+}$ reformate from the feed composition $(\mathrm{N}+2 \mathrm{~A})_{\mathrm{F}}$ and severity of catalytic reforming $\left(\mathrm{RON}_{\mathrm{R}}\right)$, where $\mathrm{N}, \mathrm{A}$, and $\mathrm{RON}_{\mathrm{R}}$ denote naphthenes (vol\%), aromatics (vol\%) and reformate RON, respectively $[62,70,71]$. Eq. (6) gives the relation between $\mathrm{RON}_{\mathrm{R}}$ and aromatic vol\% in the reformate $\left(\mathrm{A}_{\mathrm{R}}\right.$ vol\%). Table 9 shows this model can provide a reasonable estimation of DCL liquid catalytic reforming process [72]. The motor octane number (MON) of reformate can be estimated by Eq. (7) $[71,73,74]$.

$$
C_{5+}(\text { vol } \%)=142.7912-0.77033 \times R O N_{R}+0.219122 \times(N+2 A)_{F}
$$




$$
\begin{aligned}
& H_{2}(w t \%)=-12.1641+0.06134 \times C_{5+}\left(v_{0} \%\right)+0.099482 \times R O N_{R} \\
& A_{R}(v o l \%)=1.6857 \times R_{R} O N_{R}-92.994 \\
& M O N_{R}=22.5+0.83 R O N_{R}-20.0 S G
\end{aligned}
$$

Table 9

Validation of the yield model of the catalytic reforming unit.

\begin{tabular}{lllcccc}
\hline \multirow{2}{*}{ Feed composition } & \multirow{2}{*}{ Cases } & \multicolumn{2}{c}{ RON $_{\mathrm{R}}=94.2$} & \multicolumn{2}{c}{ RON $_{\mathrm{R}}=97.7$} \\
& & & Experimental & Model & Experimental & Model \\
\hline $\mathrm{N}(\mathrm{vol} \%)$ & 64.4 & $\mathrm{C}_{5+}(\mathrm{vol} \%)$ & 92.5 & 91.4 & 91.1 & 88.7 \\
$\mathrm{~A}(\mathrm{vol} \%)$ & \multirow{2}{*}{16.0} & $\mathrm{H}_{2}(\mathrm{wt} \%)$ & 2.50 & 2.81 & 3.00 & 3.00 \\
& & $\mathrm{~A}_{\mathrm{R}}(\mathrm{vol} \%)$ & 65.8 & 65.8 & 71.7 & 71.7 \\
\hline
\end{tabular}

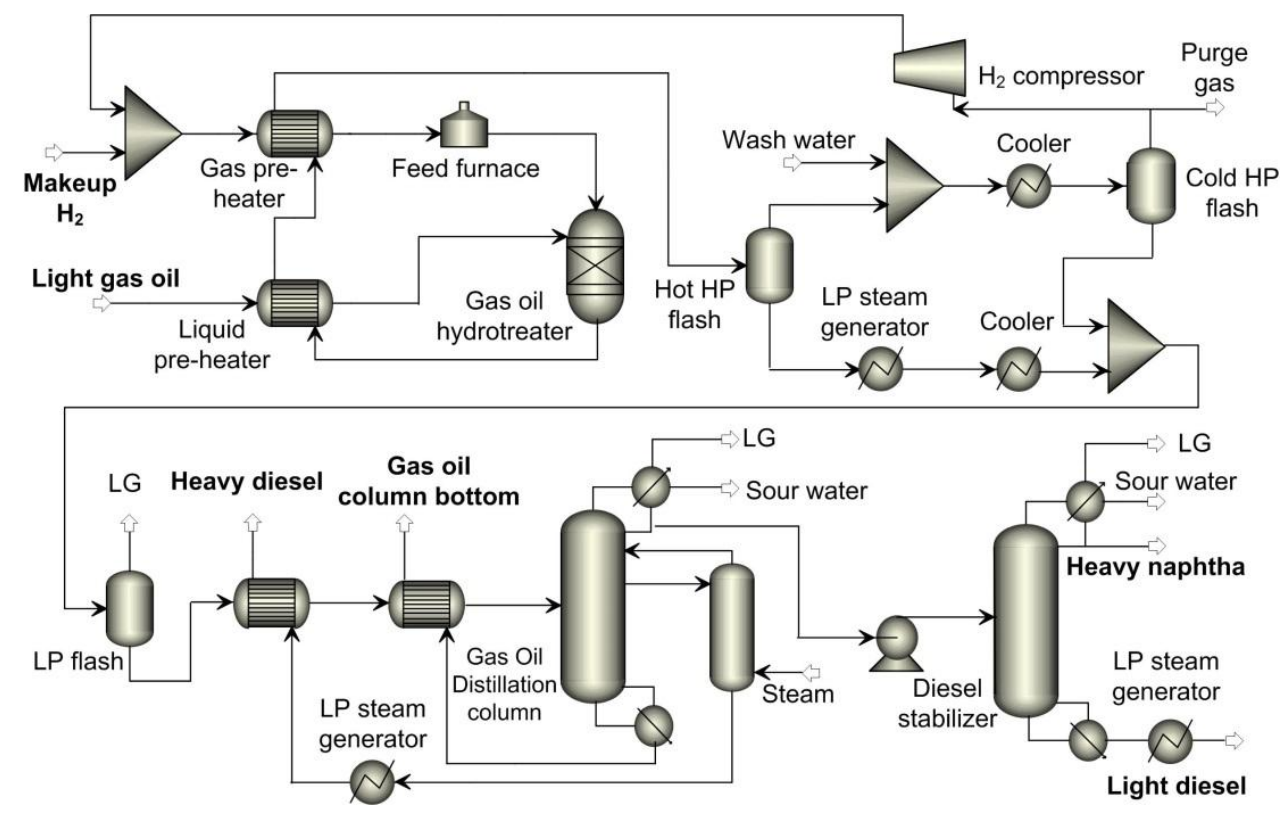

Fig. 5. Plant configuration of the gas oil hydrotreating unit.

The main purpose of the inline hydrotreater is to stabilize the liquefaction product, while the diesel cut from the inline hydrotreater does not necessarily satisfy the diesel specification [75]. Hence, the gas oil hydrotreating unit is required to produce on-spec diesel. In the gas oil hydrotreating unit, the raw gas oil is pre-heated by the hot hydrotreated gas oil and then sent to hydrotreater with heated $\mathrm{H}_{2}$ stream. $\mathrm{H}_{2}$-rich stream is recovered from the HP flash drum and recycled back to the reactor. The liquid from the LP flash vessel is sent to a distillation column followed by a diesel stabilizer to separate the hydrotreated product into light gas, heavy naphtha, diesel $\left(177-343^{\circ} \mathrm{C}\right)$, and gas oil column bottom $\left(343-454^{\circ} \mathrm{C}\right)$. The approach 
to modeling the gas oil hydrotreating reactor is the same as the inline hydrotreating reactor as described in Section 2.2.2. The gas oil hydrotreater is operated at 180 bar and $350{ }^{\circ} \mathrm{C}$ with a pressure drop of 7 bar, a temperature increase of $83{ }^{\circ} \mathrm{C}, P_{\mathrm{H}_{2}}$ of 124 bar, and a liquid hourly space velocity of $1 \mathrm{~h}^{-1}$. It can be noted that these specifications are similar to that reported by Bechtel/Amoco [51]. PetroFrac model in Aspen Plus is used to simulate the distillation column and the diesel stabilizer. Peng-Robinson EOS is used as the thermodynamic model. A 'design spec' in Aspen Plus is set up to satisfy the ASTM D86 90 vol\% specification of diesel (ASTM D975) by manipulating the bottom flowrate of the gas oil distillation column.

\subsection{Syngas production}

Significant amount of $\mathrm{H}_{2}$ is required in the direct CBTL plant. The first step to $\mathrm{H}_{2}$ production is to generate the syngas from fuels, such as natural gas, shale gas, coal, biomass and liquefaction residues. Then the raw syngas is sent to a high temperature shift (HTS) reactor and a low temperature shift (LTS) reactor, where $\mathrm{H}_{2}$ concentration in the syngas is increased by the water gas shift reaction. In order to reduce $\mathrm{H}_{2}$ production from external fuels, liquefaction residues from the ROSE-SR unit is used to produce syngas in the POX unit by gasification. Additional $\mathrm{H}_{2}$ is produced by shale gas steam reforming in the SMR_CCS and SMR_VT processes, or by coal/biomass/residue co-gasification in the CG_CCS and CG_VT processes. Throughput of the SMR or CG unit is determined by the overall hydrogen balance, as shown in Eq. (1).

\subsubsection{Shale gas steam methane reforming (SMR)}

In the SMR unit, as shown in Fig. 6, the shale gas is compressed, heated by the steam reformer outlet stream and sent to an adiabatic pre-reformer, where heavier hydrocarbons are converted to methane and syngas through Reactions 8-10. The outlet stream of the pre-reformer is reheated by exchanging heat with the stream reformer outlet stream and then sent to the steam reformer, where most of the methane is converted to syngas by Reactions 9-11. The heat required by the highly endothermic in the steam reformer is produced in the reformer furnace by burning fuel gas taken from the plant fuel gas header. The product from the stream reformer is cooled and sent to HTS and LTS reactors. The syngas from the shift reactors is cooled by generating HP, intermediate pressure (IP), and LP steams. The syngas from the LP steam generator is sent to a condenser to remove most of the water. The hot flue gas from the reformer furnace is sent to a series of heat exchangers to generate super-heated HP steam used for steam reforming. In this study, the pre-reformer and steam reformer are modeled as equilibrium reactors [76]. The HTS and LTS reactors are modeled as plug flow reactors (PFRs) with kinetics obtained from the open literature [48]. The reformer furnace is modeled as 'RStoic' reactor in Aspen Plus with specified combustion 
reactions. The Peng-Robinson EOS is used as the thermodynamic model of the syngas side, while IAPWS-95 is used for the steam side. Operating conditions of all reactors and heat exchangers can be found in Table 10.

$$
\begin{aligned}
& \mathrm{C}_{n} \mathrm{H}_{m}+\mathrm{H}_{2} \mathrm{O} \rightarrow n \mathrm{CO}+\left(m+\frac{n}{2}\right) \mathrm{H}_{2}-Q \\
& \mathrm{CO}+3 \mathrm{H}_{2} \leftrightarrow \mathrm{CH}_{4}+\mathrm{H}_{2} \mathrm{O}+Q \\
& \mathrm{CO}+\mathrm{H}_{2} \mathrm{O} \leftrightarrow \mathrm{CO}_{2}+\mathrm{H}_{2}+Q \\
& \mathrm{CH}_{4}+2 \mathrm{H}_{2} \mathrm{O} \leftrightarrow \mathrm{CO}_{2}+4 \mathrm{H}_{2}-Q
\end{aligned}
$$

\section{Table 10}

Operating conditions of the shale gas SMR unit.

\begin{tabular}{llc}
\hline Flowsheet element & Parameter & Value \\
\hline Shale gas feed & Temperature/pressure & $20{ }^{\circ} \mathrm{C} / 20 \mathrm{bar}$ \\
Compressor & Pressure & $30 \mathrm{bar}$ \\
Steam feed & Temperature/pressure & $510{ }^{\circ} \mathrm{C} / 30 \mathrm{bar}$ \\
Preheaters & Cold stream outlet temperature & $510{ }^{\circ} \mathrm{C} / 650{ }^{\circ} \mathrm{C}$ \\
Adiabatic pre-reformer & Pressure drop & $1.7 \mathrm{bar}$ \\
Steam reformer & Temperature/pressure drop & $815{ }^{\circ} \mathrm{C} / 1.7 \mathrm{bar}$ \\
HP/IP/LP steam evaporator & Hot stream outlet temperature & $350{ }^{\circ} \mathrm{C} / 215^{\circ} \mathrm{C} / 143{ }^{\circ} \mathrm{C}$ \\
Cooler & Hot stream outlet temperature & $40{ }^{\circ} \mathrm{C}$ \\
Feed water heater/economizer & Cold stream outlet temperature & $120^{\circ} \mathrm{C} / 227{ }^{\circ} \mathrm{C}$ \\
\hline
\end{tabular}

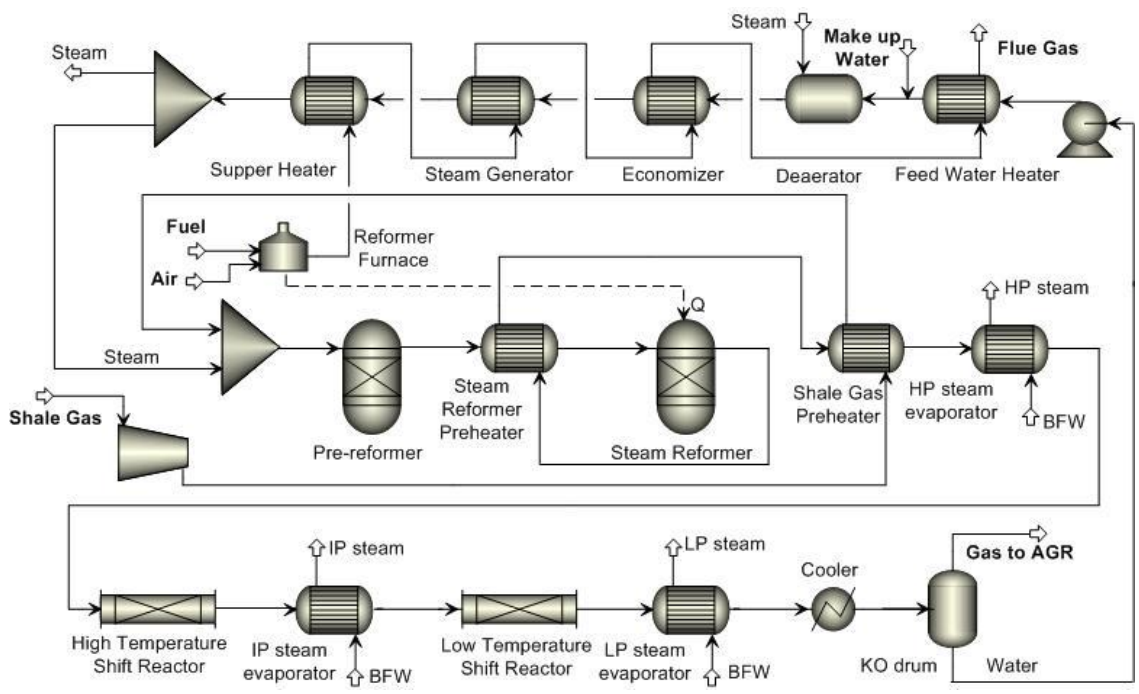

Fig. 6. Plant configuration of the shale gas SMR unit. 


\subsubsection{Residue partial oxidation (POX) and coal/biomass/residue co-gasification (CG)}

In the SMR_CCS and SMR_VT processes, the hot liquefaction residue from the ROSE-SR unit is gasified in the POX unit as shown in Fig. 7. The residue containing mainly $510{ }^{\circ} \mathrm{C}$ plus solid, ash and unconverted coal/biomass is sent to an entrained flow gasifier with $\mathrm{O}_{2}$ obtained from the air separation unit (ASU) and steam obtained from the heat recovery and steam generation (HRSG) section. In the CG_CCS and CG_VT processes, the liquefaction residue is grinded and mixed with pre-processed coal/biomass and slurry water before being fed to the entrained-flow gasifier. In all cases, the raw syngas from the gasifier is cooled and then sent to the HTS and LTS reactors to convert CO into $\mathrm{H}_{2}$ similar to the SMR unit. Flow rate of the shift steam to the HTS reactor is manipulated to achieve $95 \%$ of overall syngas $\mathrm{CO}$ conversion in the two stage water gas shift unit.

Here the gasifier is modeled as an equilibrium reactor, while the HTS and LTS reactors are modeled as PFR reactors. More details about the water gas shift reactors and co-gasifier can be found in our previous publications [2,39]. The entrained-flow gasifier fed only with the liquefaction residue is operated at 56 bar and $1315{ }^{\circ} \mathrm{C}$ with a steam to residue ratio of 0.4 and a carbon conversion of $99 \%$ similar to the data available in the open literature [23,27,28,77-79]. The amount of oxygen fed into the gasifier is manipulated to satisfy the energy balance. Simulation results from the residue gasification show that the $\mathrm{H}_{2}$ yield of the residue POX unit is about $10.2 \mathrm{wt} \%$ of the liquefaction residue [21,27].

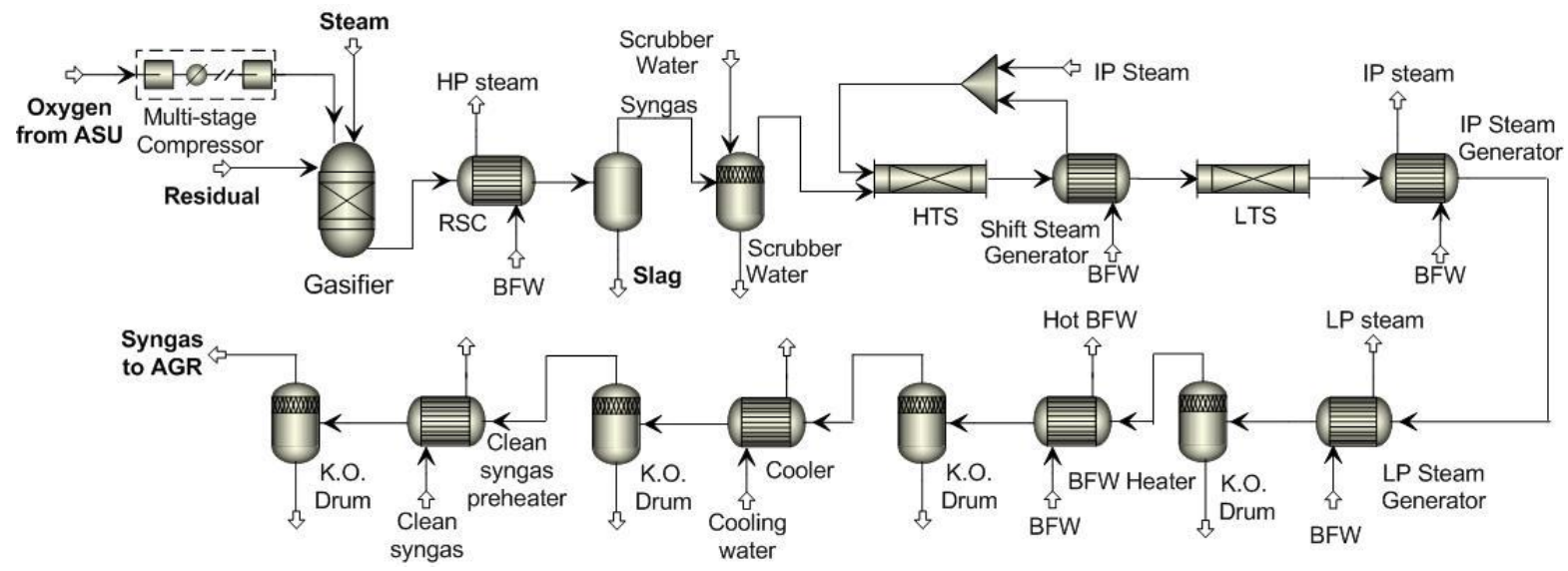

Fig. 7. Plant configuration of the POX unit.

\subsection{Acid gas removal (AGR), $\mathrm{H}_{2}$ recovery, and $\mathrm{CO}_{2}$ compression units}

The fuel gas released from the liquefaction, product recovery, and upgrading units contains $\mathrm{H}_{2} \mathrm{~S}$, which needs to be removed before being utilized in process furnaces or gas turbines. MDEA is considered to be the desired solvent for removing $\mathrm{H}_{2} \mathrm{~S}$ from fuel gas in presence of $\mathrm{CO}_{2}$ [75]. The general configuration of 
a chemical absorption process is shown in Fig. 8. The absorber is operated at $38{ }^{\circ} \mathrm{C}$ and 20 bar [75]. The 'RadFrac' model in Aspen Plus with rate-based calculations is used to simulate the absorber and stripper using the kinetics and thermal model available in the open literature [80,81].

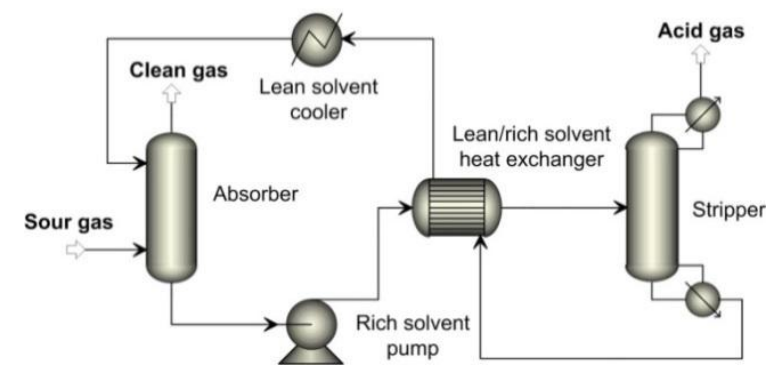

Fig. 8. Schematic of the amine-based chemical absorption process.

For all four process configurations, the gas oil column bottom and fuel gas produced in the process are sent to either process furnaces or a gas turbine, which eventually get converted to $\mathrm{CO}_{2}$, as discussed in Section 2.1. The major $\mathrm{CO}_{2}$ emission of the system is from $\mathrm{H}_{2}$ production units, process furnaces, and the gas turbine. The $\mathrm{H}_{2}$-rich syngas stream from the POX/CG unit contains not only a significant amount of $\mathrm{CO}_{2}$, but also a small amount of $\mathrm{H}_{2} \mathrm{~S}$. In order to recover pure $\mathrm{H}_{2}$, those streams are sent to the AGR unit to selectively remove $\mathrm{CO}_{2}$ and $\mathrm{H}_{2} \mathrm{~S}$, no matter if CCS is considered or not. The removed $\mathrm{CO}_{2}$ is vented or sent to the $\mathrm{CO}_{2}$ compression unit, depending on whether CCS is considered and the targeted extent of CCS. If high extent of CCS is considered, additional $\mathrm{CO}_{2}$ needs to be captured from the gas turbine flue gas using post-combustion $\mathrm{CO}_{2}$ capture technologies, and the amount is determined by carbon balance as shown in Eq. (3). In this study, physical absorption is considered for streams with high $P_{\mathrm{CO}_{2}}$, while chemical absorption is considered for steams with intermediate or low $P_{\mathrm{CO}_{2}}$.

For the physical absorption process, the acid gas partial pressure is the main driving force for absorption and has a significant effect on the process efficiency [2]. For the chemical absorption process, the acid gas partial pressure does not have much effect. For all four configurations, the dual-stage Selexol technology is applied to selectively remove $\mathrm{H}_{2} \mathrm{~S}$ and the majority of $\mathrm{CO}_{2}$ from the $\mathrm{HP}$ syngas obtained from the POX/CG unit. In the SMR_CCS and SMR_VT processes, the extent of $\mathrm{CO}_{2}$ capture is decided to make the $P_{\mathrm{CO}_{2}}$ of the clean syngas from the $\mathrm{HP} \mathrm{CO}_{2}$ absorber in the Selexol unit to be the same as $P_{\mathrm{CO}_{2}}$ of the IP syngas from the shale gas SMR unit. Then the syngas from the $\mathrm{HP} \mathrm{CO}_{2}$ absorber is mixed with the syngas from the SMR unit, and sent to an IP $\mathrm{CO}_{2}$ absorber unit using chemical solvent to further remove $\mathrm{CO}_{2}$. If high extent of CCS is considered, the amount of $\mathrm{CO}_{2}$ removed in the $\mathrm{IP}^{\mathrm{CO}} \mathrm{O}_{2}$ absorber unit is determined such that the treated gas $P_{\mathrm{CO}_{2}}$ is the same as the flue gas $P_{\mathrm{CO}_{2}}$, and this treated gas is mixed with the gas 
turbine flue gas and sent to a $\mathrm{LP} \mathrm{CO}_{2}$ absorber using chemical solvent to achieve the targeted extent of CCS. In the CG_CCS and CG_VT processes, the dual-stage Selexol technology is considered to treat the raw syngas obtained from the POX/CG unit, while an additional chemical absorption unit is required to treat the flue gas obtained from the CG_CCS process.

The plant configuration of the dual-stage Selexol unit can be found in our previous publication [48]. The configuration of the chemical absorption unit is similar to Fig. 8, where multiple absorption columns operating at different pressure is considered, since the syngas and flue gas are available at different pressures and cannot be mixed. Rich solvents from different absorbers are mixed first, and then sent to the lean/rich exchanger and then to the strippers for solvent regeneration. Absorbers in the Selexol unit are modeled by the 'RadFrac' block with equilibrium-stage modeling using the PC-SAFT EOS. MDEA/PZ and MEA are the two chemical solvents considered in this study. All absorbers and strippers in the chemical absorption unit are modeled and sized by the 'RadFrac' block with rate-based modeling using ELECNRTL EOS. Parallel trains are considered if the column diameter exceeds 10 meter. The modeling approach and reaction kinetics of the MDEA/PZ/CO 2 system and the $\mathrm{MEA} / \mathrm{CO}_{2}$ system are described in our previous publications [2].

Removed $\mathrm{H}_{2} \mathrm{~S}$ stream from the Selexol unit is mixed with the $\mathrm{H}_{2} \mathrm{~S}$ stream from the MDEA unit and then sent to the Claus unit for conversion to elemental sulfur. The extent of $\mathrm{H}_{2} \mathrm{~S}$ removal is computed by comparing the gas turbine sulfur tolerance and the $\mathrm{SO}_{2}$ emission regulation (40 CFR 60.42b) and selecting the lower value. $\mathrm{CO}_{2}$-rich streams at different pressure levels are vented or sent to different stages in a split-shaft multistage $\mathrm{CO}_{2}$ compressor, determined by the targeted extent of CCS. The clean syngas from the AGR unit is sent to the PSA unit for producing pure $\mathrm{H}_{2}$. The number of beds required for PSA units has been approximated by using the study from Bechtel [70]. Plant configuration and modeling approach of the Claus and $\mathrm{CO}_{2}$ compression units can be found in our previous publications [2,48]. The PSA unit is modeled as a component separator in Aspen Plus while designing it using the approach detailed in our previous publication [3].

\subsection{Combined cycle power island}

Most of the flue gas and waste heat produced in the product recovery and upgrading unit, the POX/CG unit and the SMR unit are utilized in the combined cycle power island. The steam generator in the combined cycle power island operates at three pressure levels and not only produces steam to generate electricity but also provides IP and LP steams needed in the POX/CG, product upgrading, and AGR units, as shown in Table 11. The modeling approach of the combined cycle plant and its pressure levels is the same as our previous study $[3,48]$. 


\section{Table 11}

Configuration of the HRSG section and steam header.

\begin{tabular}{lcccc}
\hline Steams & $\begin{array}{c}\text { Pressure } \\
(\mathrm{bar})\end{array}$ & $\begin{array}{c}\text { Temperature } \\
\left({ }^{\circ} \mathrm{C}\right)\end{array}$ & From & To \\
\hline HP steam to ST & 114 & 510 & POX, GT, SMR & ST HP section \\
IP steam to ST & 25 & 510 & $\begin{array}{c}\text { POX, SMR, HCR } \\
\text { (through reheater })\end{array}$ & ST IP section \\
LP steam to ST & 4 & 140 & $\begin{array}{c}\text { GTFG, HCR, SMR } \\
\text { POX, HCU }\end{array}$ & ST LP section \\
HP steam to header & 57 & & ST HP section & POX, HCU \\
IP steam to header & 9 & & ST IP section & AGR \\
LP steam to header & 4 & & ST LP section & AGR, HCU \\
\hline
\end{tabular}

\section{Results and discussions}

For the base case conditions, the biomass/coal weight ratio, the plant capacity and the extent of CCS are set to be 8/92 (dry basis), 10000 bbl/day, and 90\% (for SMR_CCS and CG_CCS). Here, the extent of CCS is defined by Eq. (3). The following studies are conducted for analyzing the feasibility of applying CCS and introducing shale gas and biomass into the traditional DCL processes. First, heat integration is applied to reduce the utility consumption, and the AGR unit is designed depending on the carbon balance. Then the material and energy balance of the direct CBTL processes is obtained based on the process model of the entire system and compared with the data reported in the open literature for validation. Based on the validated process model, sensitivity studies are conducted by changing the biomass/coal ratio, CCS solvent and the extent of CCS with different hydrogen sources. Finally, the direct CBTL process is compared with the indirect CBTL processes.

\subsection{Heat integration in the liquefaction and product recovery section}

Temperature changes in key streams in the liquefaction and product recovery section are shown in Fig. 9, where the cold streams are shown as bars filled with upward diagonals and the hot streams are shown as bars filled with downward diagonals. 25 heat exchangers, steam generators, heaters and coolers are designed by Aspen Energy Analyzer using pinch analysis. Table 12 lists the forbidden and matched hot and cold streams in the heat exchanger network design. Stream numbers mentioned in Fig. 9 and Table 12 are shown in Fig. 3. With the new design, the coal/biomass slurry is heated to about $350{ }^{\circ} \mathrm{C}$ by hot liquefaction product before entering the preheat furnace, while the heat duty of the preheat furnace is reduced by about $52 \%$. These results are similar to the NEDO's DCL experience, where the coal slurry is 
preheated to $340{ }^{\circ} \mathrm{C}$ in the heat exchangers and the heat duty of the furnace is reduced by about $60 \%$ $[82,83]$.

Table 12

Forbidden and matched hot and cold streams in the heat integration.

\begin{tabular}{cccccccc}
\hline & 4 & 5 & 6 & 7 & 8 & 9 & 10 \\
\hline 1 & $\checkmark$ & $\checkmark$ & $\checkmark$ & $x$ & $x$ & $\checkmark$ & \\
2 & & & $\checkmark$ & $\checkmark$ & $\checkmark$ & $x$ & $x$ \\
3 & $x$ & $\checkmark$ & $x$ & & & & $\checkmark$ \\
\hline
\end{tabular}

$\boldsymbol{x}$ - the hot and cold streams are not allowed to exchange heat

$\checkmark$ - recommended match of hot and cold streams by Aspen Energy Analyzer

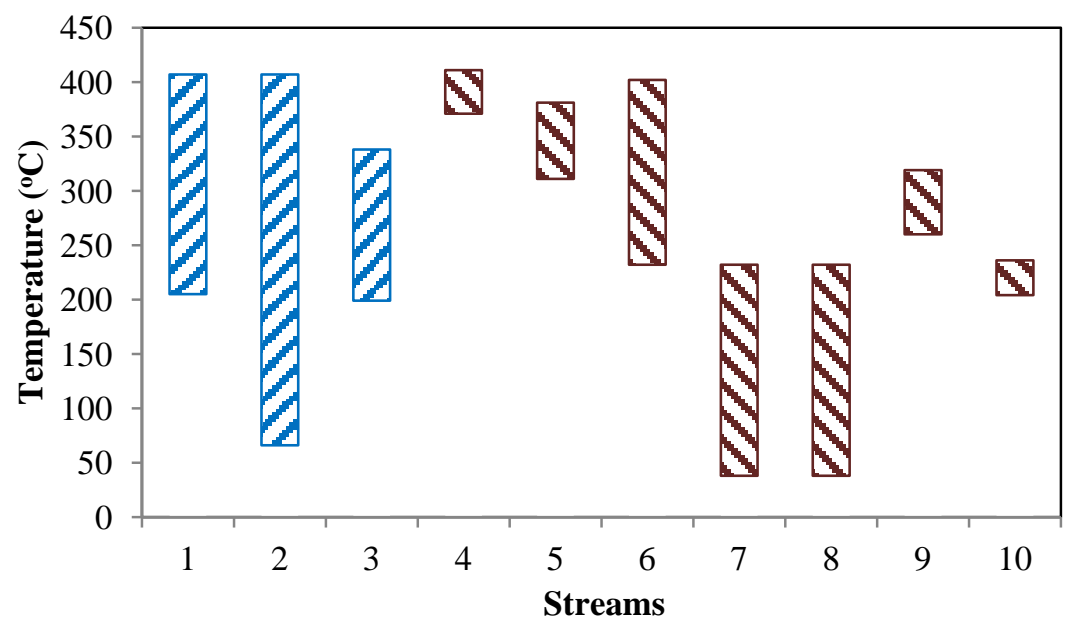

Fig. 9. Temperature chart of the liquefaction and product recovery section.

\subsection{Carbon balance and design of the $\mathrm{CO}_{2}$ removal system}

Based on the models developed for the liquefaction and product recovery section and the syngas production section, carbon balances of the direct CBTL plants are computed and shown in Table 13. In the SMR_CCS and SMR_VT processes, $53.9 \%$ of the carbon in the feedstock is converted to gasoline and diesel. In the CG_CCS and CG_VT processes, it is only $43.5 \%$ because the H/C ratio in coal and biomass is less than that in shale gas or natural gas, resulting in less efficiency in the $\mathrm{H}_{2}$ plant. In order to achieve $90 \%$ carbon capture (considered to be high level CCS in this study), another $36.1 \%$ of carbon in the feedstock (78.3\% of $\mathrm{CO}_{2}$ generated) needs to be captured by the $\mathrm{CO}_{2}$ capture process in the SMR_CCS process, and another $46.5 \%$ of carbon in the feedstock $\left(82.3 \%\right.$ of $\mathrm{CO}_{2}$ generated) needs to be 
captured in the CG_CCS process. Based on the design procedure described in Section 2.5, Table 14 through Table 16 list the main $\mathrm{CO}_{2}$ sources ordered by $P_{\mathrm{CO}_{2}}$ and flowrate, preliminary selection of absorption technologies, operating conditions and targeted extent of $\mathrm{CO}_{2}$ removal for each stream.

\section{Table 13}

Carbon balance of the direct CBTL plants ${ }^{(1)}$.

\begin{tabular}{lcclcclcc}
\hline $\begin{array}{l}\text { Carbon in } \\
(\%)\end{array}$ & SMR & CG & $\begin{array}{l}\text { Carbon out } \\
\text { (w/o utility, } \%)\end{array}$ & SMR & CG & $\begin{array}{l}\text { Carbon out } \\
\text { (w/ utility, \%) }\end{array}$ & SMR & CG \\
\hline Coal & 77.4 & 94.6 & Gasoline & 11.4 & 9.4 & Fuel & 53.9 & 43.5 \\
Biomass & 4.6 & 5.4 & Diesel & 41.2 & 34.1 & POX/CG & 10.7 & 38.8 \\
Shale gas & 18.0 & & Fuel oil & 7.0 & 5.8 & SMR & 19.2 & \\
& & & Fuel gas & 10.5 & 11.9 & Gas turbine & 9.5 & 12.1 \\
& & & H plants & 29.9 & 38.8 & Others & 6.7 & 5.6 \\
\hline
\end{tabular}

(1) Fuel gas and fuel oil produced from gas oil column bottom are treated as utility in the case with (w/) utility, but not in the case without (w/o) utility

Table 14

$\mathrm{CO}_{2}$ emission and sources in the SMR_CCS and SMR_VT processes.

\begin{tabular}{lccccccc}
\hline Source & $\begin{array}{c}\text { Carbon } \\
(\%)\end{array}$ & $\begin{array}{c}\mathrm{CO}_{2} \\
(\mathrm{~mol} \%)\end{array}$ & $\begin{array}{c}\mathrm{P}_{\mathrm{CO}_{2}} \\
(\mathrm{bar})\end{array}$ & $\begin{array}{c}\mathrm{CO}_{2} \\
\text { removal }\end{array}$ & $\begin{array}{c}\mathrm{SO}_{2} \\
\text { removal }\end{array}$ & Technology & $\begin{array}{c}\mathrm{CO}_{2} \text { removal } \\
(\%)\end{array}$ \\
\hline POX (syngas) & 11 & 36 & 18.5 & Yes & Yes & $\begin{array}{c}\text { Selexol, } \\
\text { Amine }\end{array}$ & 83.6 \\
SMR (syngas) & 12 & 19 & 3.9 & Yes & No & Amine & 98.3 \\
SMR furnace (flue gas) & 7 & 7 & 0.07 & Yes & No & Amine & 86.3 \\
Gas turbine (flue gas) & 9 & 3 & 0.03 & $\mathrm{Yes}^{(1)}$ & No & Amine & 66.5 \\
Others (flue gas) & 8 & & & No & No & N/A & \\
\hline
\end{tabular}

(1) Not considered in the SMR_VT processes

Table 15

$\mathrm{CO}_{2}$ emission and sources in the CG_CCS and $\mathrm{CG}_{-} \mathrm{VT}$ processes.

\begin{tabular}{lccccccc}
\hline Source & $\begin{array}{c}\text { Carbon } \\
(\%)\end{array}$ & $\begin{array}{c}\mathrm{CO}_{2} \\
(\mathrm{~mol} \%)\end{array}$ & $\begin{array}{c}\mathrm{P}_{\mathrm{CO}_{2}} \\
(\mathrm{bar})\end{array}$ & $\begin{array}{c}\mathrm{CO}_{2} \\
\text { removal }\end{array}$ & $\begin{array}{c}\mathrm{SO}_{2} \\
\text { removal }\end{array}$ & Technology & $\begin{array}{c}\mathrm{CO}_{2} \text { removal } \\
(\%)\end{array}$ \\
\hline CG (syngas) & 39 & 40 & 21.6 & Yes & Yes & Selexol & 95.0 \\
Gas turbine (flue gas) & 12 & 3 & 0.03 & $\mathrm{Yes}^{(1)}$ & $\mathrm{No}$ & Amine & 69.8 \\
Others (flue gas) & 6 & & & $\mathrm{No}$ & No & N/A & \\
\hline
\end{tabular}

(1) Not considered in the CG_VT processes 
Table 16

Configurations and operating conditions of the AGR units.

\begin{tabular}{lccc}
\hline Column & Pressure (bar) & Sour gas from & Clean gas to \\
\hline $\mathrm{HP} \mathrm{CO}_{2}$ absorber & 50.5 & $\begin{array}{c}\text { POX/CG (syngas) } \\
\mathrm{SMR}_{\text {(syngas) and/or }}\end{array}$ & $\mathrm{H}_{2}$ recovery \\
IP absorber ${ }^{(1)}$ & 20.7 & $\begin{array}{c}\text { Selexol CO } \\
\text { Gas turbine (flue gas) and/or } \\
\text { SMR furnace (flue gas) }\end{array}$ & Stack \\
\hline
\end{tabular}

(1) Not considered in the CG_CCS and CG_VT processes

(2) Not considered in the SMR_VT and CG_VT processes

Based on the process model developed in Aspen Plus, the utility consumption and cost of the $\mathrm{CO}_{2}$ removal and compression units are calculated and shown in Table 17 for all four configurations with a plant capacity of $10000 \mathrm{bbl} / \mathrm{day}$. For the SMR_CCS (base case) process, two different amine solvent are considered- MEA and MDEA/PZ. Utility consumptions in the Selexol unit, the amine unit and the $\mathrm{CO}_{2}$ compression unit are similar to the data available in the open literature [2, 46-48]. The reboiler duty of the solvent stripper is $3590 \mathrm{~kJ} / \mathrm{kg}$ if MEA is used as a solvent in the SMR_CCS process. This duty can be reduced by $14 \%$ if using MDEA/PZ as the solvent [2]. Hence, MDEA/PZ is selected for removing $\mathrm{CO}_{2}$ from IP and $\mathrm{LP} \mathrm{CO}_{2}$-contianing streams in all case studies and sensitivity studies. Table 17 also indicates that utility costs for the CG_CCS and SMR_CCS processes are similar. The CCS utility cost for the CG_VT process is lower than the SMR_VT process, even though more $\mathrm{CO}_{2}$ needs to be captured in the CG_VT process due to the lower carbon efficiency. The reason is that $P_{\mathrm{CO}_{2}}$ of most $\mathrm{CO}_{2}$-containing streams to be sent to the AGR unit is higher in the CG_CCS and CG_VT processes than that in the SMR_CCS and SMR_VT processes, as shown in Table 14 and 15. As a result, in the CG_CCS and CG_VT processes, most of the $\mathrm{CO}_{2}$ is captured by the Selexol unit instead of the amine unit resulting in lesser utility penalty for $\mathrm{CO}_{2}$ capture. The study shows that the CCS technology plays a key role in the overall utility consumption in these plants. While this paper considers only solvent-based technologies due to their maturity, novel technologies for $\mathrm{CO}_{2}$ capture such as those based on solid sorbents or membranes can be potentially evaluated as alternatives for reducing the penalty for $\mathrm{CO}_{2}$ capture.

\section{Table 17}

Utility consumptions in and costs for the CCS units.

\begin{tabular}{lccccc}
\hline Process & SMR_CCS & SMR_CCS & SMR_VT & CG_CCS & CG_VT \\
\hline $\begin{array}{l}\mathrm{CO}_{2} \text { captured } \\
(\mathrm{kmol} / \mathrm{hr})\end{array}$ & 2660 & 2660 & 1733 & 4245 & 3367 \\
Amine solvent & MEA & MDEA/PZ & MDEA/PZ & MDEA/PZ & N/A \\
\hline
\end{tabular}




\begin{tabular}{lccccc}
\hline \multicolumn{5}{l}{ Utility consumptions (electricity $(\mathrm{MW}) / \mathrm{IP}$ steam $(\mathrm{GJ} / \mathrm{hr}) / \mathrm{LP}$ steam $(\mathrm{GJ} / \mathrm{hr}) /$ cooling water $(\mathrm{GJ} / \mathrm{hr}))$} \\
Selexol unit & $1.98 / 3 / 0 / 57$ & $1.98 / 3 / 0 / 57$ & $1.98 / 3 / 0 / 57$ & $8.32 / 29 / 0 / 255$ & $8.32 / 29 / 0 / 255$ \\
Amine unit & $0.94 / 0 / 309 / 389$ & $0.92 / 0 / 297 / 377$ & $0.34 / 0 / 78 / 77$ & $0.46 / 0 / 229 / 343$ & $0 / 0 / 0 / 0$ \\
Compression & $9.59 / 0 / 0 / 48$ & $9.59 / 0 / 0 / 48$ & $0 / 0 / 0 / 0$ & $11.58 / 0 / 0 / 61$ & $0 / 0 / 0 / 0$ \\
Total & $12.5 / 3 / 309 / 494$ & $12.5 / 3 / 297 / 482$ & $2.3 / 3 / 78 / 134$ & $20.4 / 29 / 229 / 659$ & $8.3 / 29 / 0 / 255$ \\
$\mathrm{Cost}^{(2)}(\$ / \mathrm{h})$ & 5077 & 4913 & 1265 & 4919 & 993 \\
\hline
\end{tabular}

(1) If high extent of CCS is considered, flue gas needs to be cooled before sending it to the amine system. The extra cooler is included in the amine unit.

(2) Costs of electricity, IP steam, LP steam and cooling water are assumed to be $\$ 16.8, \$ 14.19, \$ 13.28$ and $\$ 0.354$ per GJ [84].

\subsection{Material and energy balance and model validation}

Using the steady-state process model developed in Aspen Plus ${ }^{\circledR}$ and the design of the AGR unit shown in Section 3.2, material and energy balances are computed for all four configurations. For the base case, SMR_CCS, the flow rate of the key species in the main streams numbered in Fig. 1 can be found in Appendix B. Due to the limited information on applications of CCS technologies for DCL processes, simulation results are only validated for the SMR_VT and CG_VT processes. The utility consumption in CCS related facilities is validated separately in Section 3.2. It is generally accepted that the DCL processes without CCS usually have a thermal efficiency between $60 \%$ and $70 \%$ [75]. As shown in Table 18, results from our study are in-between the values reported by HTI (73.4\%) and Shenhua (59.8\%) and seem reasonable [1, 2154,85$]$. The differences are mainly due to different types of coal, sources of hydrogen and process utilities. The carbon and hydrogen content varies with the types of coal, which leads to different hydrogen requirement for liquefaction. Because of the different $\mathrm{H} / \mathrm{C}$ ratio in coal and shale gas, the hydrogen production efficiency is very different between the coal gasification process and shale gas steam reforming process. Due to the difference in heating value and conversion efficiency of different type of energy sources, types of power and fuel source also affect the overall thermal efficiency of the direct CBTL processes. Detailed material and energy balances for all four configurations can be found in Table 19, which indicates that the thermal efficiency of the direct CBTL plant can be significantly increased by producing hydrogen from shale gas. Application of CCS will reduce the thermal efficiency by $2.2 \%$ if $\mathrm{H}_{2}$ is produced from steam reforming or $2.1 \%$ if $\mathrm{H}_{2}$ is produced by gasification, which is similar because the penalty of CCS is similar as discussed in Section 3.2. It can be concluded from Table 19 that utilization of shale gas or natural gas in the DCL process can increase the competitiveness of this technology, if shale gas or natural gas is available at lower price within reasonable transportation distance. 


\section{Table 18}

Comparison between the simulation results and data in the open literature.

\begin{tabular}{|c|c|c|c|c|c|c|c|}
\hline Process & SMR_VT & CG_VT & $\begin{array}{c}\text { HTI } \\
\text { design }^{(1)}\end{array}$ & $\begin{array}{c}\text { Modified } \\
\text { HTI } \\
\text { design }^{(2)}\end{array}$ & $\begin{array}{c}\text { Bechtel/ } \\
\text { Amoco } \\
\text { design }^{(3)}\end{array}$ & $\begin{array}{c}\text { Modified } \\
\text { Bechtel/ } \\
\text { Amoco } \\
\text { design }\end{array}$ & $\begin{array}{c}\text { Shenhua } \\
\text { design }\end{array}$ \\
\hline Reference & & & [29] & [29] & [1] & [1] & [85] \\
\hline Biomass (wt \%) & 8 & 8 & 0 & 0 & 0 & 0 & 0 \\
\hline $\begin{array}{l}\text { Hydrogen } \\
\text { source }\end{array}$ & Shale gas & $\begin{array}{c}\text { Coal/ } \\
\text { biomass }\end{array}$ & $\begin{array}{l}\text { Natural } \\
\text { gas }\end{array}$ & Coal & Coal & Coal & Coal \\
\hline $\begin{array}{l}\text { Power and fuel } \\
\text { source }\end{array}$ & Fuel gas ${ }^{(4)}$ & Fuel gas $^{(4)}$ & N/A & N/A & Natural gas & Coal & Coal \\
\hline $\begin{array}{l}\text { Efficiency } \\
(\mathrm{HHV}, \%)\end{array}$ & 66.5 & 62.1 & 73.4 & 70.9 & 61.6 & 59.0 & 59.8 \\
\hline
\end{tabular}

(1) In the original HTI design, utility consumptions are not considered during the efficiency calculation.

(2) It is assumed that the effective thermal efficiency is $57.5 \%$ on HHV basis for producing $\mathrm{H}_{2}$ from coal gasification. [1]

(3) Estimations are based on the HTI technology for liquefaction, while utility consumptions are considered.

(4) Fuel gas is generated insider plant mainly from the liquefaction unit and product upgrading units.

Table 19

Material and energy balances of the direct CBTL plant (HHV basis $\left.{ }^{(1)}\right)$.

\begin{tabular}{lcccc}
\hline Process & SMR_CCS & SMR_VT & CG_CCS & CG_VT \\
\hline Energy inputs & & & & \\
Coal, tonne/hr (GJ/hr) & $100.1(2962)$ & $100.1(2962)$ & $151.4(4479)$ & $151.4(4479)$ \\
Biomass, tonne/hr (GJ/hr) & $9.3(163)$ & $9.3(163)$ & $14.1(247)$ & $14.1(247)$ \\
Shale gas, tonne/hr (GJ/hr) & $21.6(1105)$ & $21.6(1105)$ & N/A & N/A \\
Energy outputs & & & & \\
Gasoline, bbl/day (GJ/hr) & $2443(595)$ & $2443(595)$ & $2443(595)$ & $2443(595)$ \\
Diesel, bbl/day (GJ/hr) & $7557(1936)$ & $7557(1936)$ & $7557(1936)$ & $7557(1936)$ \\
Net power (MW) & 52.4 & 77.8 & 84.5 & 111.9 \\
Thermal efficiency (\%) & 64.3 & 66.5 & 60.0 & 62.1 \\
\hline
\end{tabular}

(1) HHVs of gasoline and diesel are set to be 5.84 and $6.15 \mathrm{GJ} / \mathrm{bbl}[1]$.

\subsection{Effects of the biomass to coal mix ratio}

In this study, three biomass/coal weight ratios are investigated. The upper bound of biomass/coal weight ratio is set to be 20/80, because the capacity of BTL or CBTL plants is constrained due to the high transportation cost, low energy density and limited long-term availability of biomass.[16,17] Table 20 and 
Table 21 show that the thermal efficiency and carbon efficiency of the direct CBTL plant keep increasing for both SMR_CCS and CG_CCS processes, as more biomass is added to the liquefaction reactor. Even though $\mathrm{H}_{2}$ consumption in the hydrotreating processes increases with the biomass/coal ratio due to the higher oxygenates contents, overall $\mathrm{H}_{2}$ consumption in the direct CBTL plant decreases with the biomass/coal ratio, because the higher $\mathrm{H} / \mathrm{C}$ ratio in the biomass reduces the $\mathrm{H}_{2}$ consumption in the main liquefaction reactor more significantly. As a consequence, an increase in the biomass/coal ratio decreases the amount of shale gas or additional coal and biomass required for $\mathrm{H}_{2}$ production, leading to an increase in the overall carbon efficiency and a decrease in the amount of $\mathrm{CO}_{2}$ needed to be captured to achieve overall $90 \%$ carbon capture. With less $\mathrm{CO}_{2}$ captured, less steam and electricity are consumed by the CCS facilities. Hence, the overall thermal efficiency of the CBTL plants is increasing with the biomass/coal ratio for both SMR_CCS and CG_CCS processes. Even though the simulation results shows that adding biomass to the traditional DCL process can increasing the process efficiency and reduce $\mathrm{CO}_{2}$ emission, it should be noted that the overall cost of biomass and the capital cost of the pre-processing unit is usually higher than coal due to the lower energy density. [4] To decide whether to introduce biomass and what biomass/coal ratio to use, other than efficiency calculation shown here, additional studies such as technoeconomic analysis, life-cycle analysis and biomass logistic analysis are required. [17]

\section{Table 20}

Effects of the coal biomass mix ratio (SMR_CCS, 10k bbl/day).

\begin{tabular}{lccc}
\hline Biomass/coal (wt/wt) & $8 / 92$ & $15 / 85$ & $20 / 80$ \\
\hline Coal (tonne/hr) & 100.1 & 90.1 & 84.2 \\
Biomass (tonne/hr) & 9.3 & 17.6 & 22.7 \\
Shale gas (tonne/hr) & 21.6 & 20.7 & 20.3 \\
Thermal efficiency $(\%$, HHV) & 64.3 & 66.5 & 67.6 \\
Total $\mathrm{H}_{2}$ consumption $(\%$ daf feed) & 8.61 & 8.24 & 8.05 \\
Liquefaction $\mathrm{H}_{2}$ consumption (\% daf feed) & 6.70 & 6.20 & 6.00 \\
Carbon efficiency (\%) $_{\mathrm{CO}_{2} \text { captured }(\mathrm{kmol} / \mathrm{hr})}^{53.9}$ & 56.4 & 57.6 \\
\hline
\end{tabular}

Table 21

Effects of the coal biomass mix ratio (CG_CCS, 10k bbl/day).

\begin{tabular}{lccc}
\hline Biomass/coal $(\mathrm{wt} / \mathrm{wt})$ & $8 / 92$ & $15 / 85$ & $20 / 80$ \\
\hline Coal (tonne/hr) & 151.4 & 138.8 & 132.0 \\
Biomass (tonne/hr) & 14.1 & 26.8 & 35.4 \\
Thermal efficiency $(\%, \mathrm{HHV})$ & 60.0 & 61.5 & 62.1 \\
Total $\mathrm{H}_{2}$ consumption $(\%$ daf feed) & 8.61 & 8.24 & 8.05 \\
\hline
\end{tabular}




\begin{tabular}{llll}
\hline Liquefaction $\mathrm{H}_{2}$ consumption ( \% daf feed) & 6.70 & 6.20 & 6.00 \\
Carbon efficiency (\%) & 43.5 & 45.1 & 45.6 \\
$\mathrm{CO}_{2}$ captured $(\mathrm{kmol} / \mathrm{hr})$ & 4245 & 3959 & 3852 \\
\hline
\end{tabular}

\subsection{Effects of the extent of CCS}

As mentioned earlier, CCS is not considered in the SMR_VT and CG_VT processes, where $\mathrm{CO}_{2}$ is removed from the syngas for hydrogen purification and directly vented to the atmosphere. If the concept of carbon tax or other potential GHG emission related regulation is implemented, the CCS facility will be a necessary part of those alternative fuel production processes. The extent of CCS will be determined by local regulations if applicable. As the penalty of CCS does not increase linearly with the extent of CCS, it is necessary to redesign the process appropriately while evaluating effects of different level of CCS. For the SMR_CCS and CG_CCS processes, effects of low and high extent of CCS are studied. If low extent of CCS is considered, the removed $\mathrm{CO}_{2}$ from the syngas is sent to the $\mathrm{CO}_{2}$ compressor for sequestration, and no additional $\mathrm{CO}_{2}$ needs to be removed from the flue gas. On the other hand, when high extent of CCS is considered in the SMR_CCS and CG_CCS processes, additional $\mathrm{CO}_{2}$ is captured from the flue gas and sent to the $\mathrm{CO}_{2}$ compressor along with the $\mathrm{CO}_{2}$ captured from the syngas for being sent to the $\mathrm{CO}_{2}$ pipeline. Table 22 and 23 show the effect of the extent of CCS on the thermal efficiency and $\mathrm{CO}_{2}$ emission with different biomass/coal ratios and hydrogen sources. It is observed that the $\mathrm{CO}_{2}$ emission of the direct CBTL plant with the hydrogen produced from the shale gas can be reduced by more than half with the thermal efficiency reduced by only $0.5 \%$, if low extent of CCS is considered. On the other hand, high extent of CCS will reduce the thermal efficiency by another $1-1.5 \%$ because of the higher penalty of post-combustion $\mathrm{CO}_{2}$ capture facilities. The difference between low and high extent of CCS is higher in direct CBTL plants with hydrogen produced from gasification, because most of the $\mathrm{CO}_{2}$ is generated in the gasification unit with higher partial pressure, and therefore the Selexol technology that has lower penalty than the amine-based technologies can be applied for $\mathrm{CO}_{2}$ capture. It is also noticed that with the increasing biomass/coal ratio for both cases, the CCS penalty is reduced, because less $\mathrm{CO}_{2}$ needs to be captured.

Table 22

Effects of the extent of CCS (SMR_CCS and SMR_VT).

\begin{tabular}{lcccccc}
\hline $\begin{array}{l}\text { Biomass/coal (wt/wt) } \\
\text { Extent of CCS }\end{array}$ & High & Low & No & High & Low & No \\
\hline $\mathrm{CO}_{2}$ emission & 12.0 & 26.3 & 53.2 & 11.5 & 21.9 & 47.2 \\
$\left(\mathrm{~kg} \mathrm{CO}_{2} / \mathrm{GJ}\right.$ product) & 64.3 & 66.0 & 66.5 & 67.6 & 68.7 & 69.2 \\
Thermal efficiency & & & & & & \\
\hline
\end{tabular}


Table 23

Effects of the extent of CCS (CG_CCS and CG_VT).

\begin{tabular}{lcccccc}
\hline $\begin{array}{l}\text { Biomass/coal (wt/wt) } \\
\text { Extent of CCS }\end{array}$ & High & Low & No & High & Low & No \\
\hline $\begin{array}{l}\mathrm{CO}_{2} \text { emission } \\
\text { (kg CO} / \text { GJ product) }\end{array}$ & 14.3 & 27.3 & 77.4 & 13.8 & 23.5 & $72.7^{(1)}$ \\
$\begin{array}{l}\text { Thermal efficiency } \\
\text { (HHV, \%) }\end{array}$ & 60.0 & 61.2 & 62.1 & 62.1 & 63.1 & 63.6 \\
\hline
\end{tabular}

(1)The $\mathrm{CO}_{2}$ emission from the CG_VT process with low biomass/coal ratio is $72.7 \mathrm{~kg} \mathrm{CO}_{2}$ per GJ product, about 0.5 tonne/bbl oil, which is similar to the data reported by Shenhua [7].

\subsection{Direct CBTL plants vs indirect CBTL plants}

ICL and DCL are two commercially proven but very different approaches to produce transportation fuels from coal. The performance of the direct and indirect CBTL plants with a biomass/coal weight ratio of $8 / 92$ is compared in this section, based on the detailed plant-wide models developed in this study and our previous studies $[2,3]$. Table 24 shows that the $\mathrm{CO}_{2}$ emission from the indirect CBTL plant is much higher than the direct CBTL plant, while the thermal efficiency is much lower. That is because more carbon in the feedstock is converted to fuels instead of $\mathrm{CO}_{2}$ in the direct liquefaction processes. Table 24 also indicates that the comparative CCS penalty is less in the indirect CBTL plant with high extent of CCS, because most of the $\mathrm{CO}_{2}$ is produced in either gasification or Fisher-Tropsch unit and is available at higher partial pressure. In addition, no $\mathrm{CO}_{2}$ needs to be removed from low pressure flue gas in the indirect approach. Even though the direct CBTL plant, especially with shale gas utilization, is superior to the indirect CBTL plant in terms of carbon and thermal efficiency, it should be noted that a detailed technoeconomic analysis including assessment of availability of shale gas, in particular, is needed for fair comparison and final decision on commercial application.

Table 24

Performance of the direct and indirect CBTL plants.

\begin{tabular}{lcccccc}
\hline Process & \multicolumn{2}{c}{ Indirect } & \multicolumn{4}{c}{ Direct } \\
\hline Hydrogen source & \multicolumn{2}{c}{ N/A } & \multicolumn{2}{c}{ Shale gas } & \multicolumn{2}{c}{ Coal/biomass } \\
Carbon efficiency (\%) & \multicolumn{2}{c}{36.4} & \multicolumn{2}{c}{53.9} & \multicolumn{2}{c}{43.5} \\
Extent of CCS & High & No & High & No & High & No \\
Thermal efficiency (HHV, \%) & 46.6 & 48.0 & 64.3 & 66.0 & 60.0 & 62.1
\end{tabular}




\section{Conclusions}

Plant-wide models of direct CBTL plants with four different configurations are developed to analyze the effect of shale gas utilization and CCS on the plant performance. Utility consumption in the liquefaction and product recovery section can be reduced by $52 \%$ through heat integration. The AGR unit is designed based on the carbon balance and the $\mathrm{CO}_{2}$ partial pressure. Simulation results are validated by comparing with the data available in the open literature. The process model shows that the carbon efficiency of the direct CBTL plant without shale gas utilization is $43.5 \%$, which is $7.1 \%$ higher than the indirect CBTL plant with a biomass/coal weight ratio of $8 / 92$. The carbon efficiency can be increased to $53.9 \%$ if shale gas is utilized for hydrogen production. It is also observed that the direct CBTL plant with hydrogen produced from the shale gas has the highest thermal efficiency, $66.5 \%$ without CCS and $64.3 \%$ with high extent of CCS, while the indirect CBTL plant has lower thermal efficiency because of its poor carbon efficiency. Carbon and thermal efficiencies of the direct CBTL plant are found to increase with the biomass/coal ratio regardless of the hydrogen source, because the higher $\mathrm{H} / \mathrm{C}$ ratio in biomass than in coal reduces hydrogen consumption in the liquefaction unit. Sensitivity studies on the extent of CCS show that the penalty per unit of $\mathrm{CO}_{2}$ capture increases with the extent of CCS, because it costs more utility to capture $\mathrm{CO}_{2}$ from low pressure sources. Similarly, utility consumption in the CCS facilities in the direct liquefaction plant is higher than in the indirect liquefaction plant with high extent of $\mathrm{CCS}$, due to $\mathrm{CO}_{2}$ capture from the low pressure flue gas. In general, the direct CBTL plant with shale gas utilization has the best performance in terms of carbon and thermal efficiency. In closing, we would like to note this study has mainly focused on process systems analysis, but for selecting the optimal process technology and process configuration, other studies such as optimization, techno-economic analysis, and life-cycle analysis need to be conducted where the process model developed in this work can be leveraged.

\section{Acknowledgement}

The authors gratefully acknowledge financial support from U.S. Department of Energy [grant number DE-FE0009997] titled "Feasibilities of a Coal-Biomass to Liquids Plant in Southern West Virginia".

\section{Appendix A. Design of the distillation columns}

Specifications of the atmospheric and vacuum distillation columns in the product recovery section are listed in Table A.1 to Table A.4 [86,87]. 


\section{Table A.1}

Specifications of the atmospheric distillation column.

\begin{tabular}{lc}
\hline Specifications & Value \\
\hline & \multicolumn{1}{c}{ Number of trays } \\
Main column & 29 \\
Heavy naphtha side-stripper & 5 \\
Distillate side-stripper & 5 \\
& \\
Feed to main column (Furnace) & 26 \\
Stripping steam to main column (Above stage) & 30 \\
Heavy naphtha side-stripper draw and return & 15,14 \\
Distillate side-stripper draw and return & 24,23 \\
\hline
\end{tabular}

\section{Table A.2}

Operating conditions in the atmospheric distillation column.

\begin{tabular}{llll}
\hline Operating Condition & Value & \\
\hline & Main Column & & \\
Condenser temperature & 37.8 & ${ }^{\circ} \mathrm{C}$ \\
Overhead pressure & 240 & $\mathrm{kPa}$ \\
Pressure drop per tray & 1.38 & $\mathrm{kPa}$ \\
Feed furnace fractional overflash & 3.2 & $\% \mathrm{LV}$ \\
Bottom product/feed & 0.62 & $\mathrm{~kg} / \mathrm{kg}$ \\
Stripping steam/bottom product & & 4.54 & $\mathrm{~kg} / \mathrm{bbl}$ \\
& Side-strippers & 2.27 & $\mathrm{~kg} / \mathrm{bbl}$ \\
Stripping steam/heavy naphtha & & 2.27 & $\mathrm{~kg} / \mathrm{bbl}$ \\
\hline Stripping steam/diesel & & & \\
\hline
\end{tabular}

\section{Table A.3}

Specifications of the vacuum distillation column.

\begin{tabular}{lc}
\hline Specification & Value \\
\hline Total number of trays & 6 \\
Feed to main column (Furnace) & 6 \\
Stripping steam to main column (Above stage) & 7 \\
LVGO sidestream product & 2 \\
Top pump-around draw and return & 2,1 \\
HVGO sidestream product & 4 \\
HVGO pump-around draw and return & 4,3 \\
\hline
\end{tabular}


Table A.4

Operating conditions in the vacuum distillation column.

\begin{tabular}{lrl}
\hline Operating Condition & Value & \\
\hline Overhead pressure & 60 & $\mathrm{mmHg}$ \\
Bottom pressure & 70 & $\mathrm{mmHg}$ \\
Feed furnace fractional overflash & 0.6 & $\% \mathrm{LV}$ \\
Stripping steam/bottom product & 2.27 & $\mathrm{~kg} / \mathrm{bbl}$ \\
\hline
\end{tabular}

\section{Appendix B. Material balance of the direct CBTL plant base case}

Table B.1 provides the temperature, pressure and key component flowrates for main streams in the SMR_CCS process with a capacity of $10000 \mathrm{bbl} /$ day and a biomass/coal weight ratio of 8/92. The streams are numbered in Fig. 1.

\section{Table B.1}

Stream summary of the SMR_CCS process.

\begin{tabular}{lccccccccccc}
\hline Stream & 1 & 2 & 3 & 4 & 5 & 6 & 7 & 8 & 9 & 10 & 11 \\
\hline Temperature $\left({ }^{\circ} \mathrm{C}\right)$ & 27 & 21 & 35 & 432 & 267 & 414 & 93 & 302 & 35 & 36 & 36 \\
Pressure (bar) & 1 & 20 & 22 & 208 & 1 & 208 & 3 & 55 & 55 & 3 & 3 \\
Flow rate (kg/s) & & & & & & & & & & & \\
Coal & 27.81 & & & 1.03 & & & & 1.03 & & & \\
Biomass & 2.59 & & & & & & & & & & \\
$\mathrm{H}_{2} \mathrm{O}$ & & & 0.06 & 3.18 & & 2.72 & & & 0.01 & & \\
$\mathrm{CO}_{2}$ & & 0.14 & 11.55 & 1.88 & & 1.77 & & & 9.89 & & \\
$\mathrm{CO}$ & & & 0.12 & 0.63 & & 0.61 & & & 0.30 & & \\
$\mathrm{H}_{2}$ & & & 2.04 & 2.52 & & 2.43 & & & 0.74 & 2.41 & 0.14 \\
$\mathrm{H}_{2} \mathrm{~S}$ & & & & 2.01 & & 1.85 & & & 0.22 & & \\
$\mathrm{NH}_{3}$ & & & & 0.88 & & 0.81 & & & & & \\
$\mathrm{CH}_{4}$ & 4.73 & 1.67 & 1.89 & & 1.81 & & & 0.02 & & \\
$\mathrm{C}_{2}-\mathrm{C}_{4}$ & 1.09 & & 3.50 & & 3.23 & & & & & \\
$\mathrm{C}_{5}-177^{\circ} \mathrm{C}$ & & & 5.15 & & 4.13 & 3.56 & & & & \\
$177-288^{\circ} \mathrm{C}$ & & & 8.24 & & 4.89 & 6.65 & & & & \\
$288-344^{\circ} \mathrm{C}$ & & & 8.05 & 2.59 & 3.43 & 6.29 & & & & \\
$344-454^{\circ} \mathrm{C}$ & & & 41.37 & 40.62 & 10.81 & 1.11 & & & & \\
$454{ }^{\circ} \mathrm{C}+$ & & & 15.63 & 13.57 & 1.09 & & 2.53 & & & \\
$\mathrm{Ash}$ & & & 3.04 & 0.03 & & & 2.88 & & & \\
\hline
\end{tabular}




\section{Nomenclature}

$\mathrm{A}=\mathrm{ash}$

AGR = acid gas removal

$\mathrm{ASU}=$ air separation unit

$\mathrm{BFD}=$ block flow diagram

$\mathrm{CBTL}=$ coal biomass to liquids

$\mathrm{CCS}=\mathrm{CO}_{2}$ capture and storage

$\mathrm{CSD}=$ critical solvent deashing

CTSL $=$ catalytic two stage liquefaction

$\mathrm{DCL}=$ direct coal liquefaction

EDS $=$ Exxon Donor Solvent

EOS $=$ equation of state

FBP = final boiling point

$\mathrm{FC}=$ fixed carbon

$\mathrm{FG}=$ fuel gas

$\mathrm{CG}=$ co-gasification

$\mathrm{GHG}=$ greenhouse gases

$\mathrm{GT}=$ gas turbine flue gas

HCR $=$ hydrocarbon recovery

$\mathrm{HCU}=$ hydrocarbon upgrading

HDT $=$ hydrotreating

$\mathrm{HP}=$ high pressure

HRSG $=$ heat recovery and steam generation

HTI $=$ Hydrocarbon Technologies Inc.

HTS = high temperature shift

$\mathrm{HVGO}=$ heavy vacuum gas oil
IBP = initial boiling point

$\mathrm{ICL}=$ indirect coal liquefaction

IGCC $=$ integrated gasification combined

cycle

$\mathrm{LG}=$ light gas

$\mathrm{IP}=$ intermediate pressure

$\mathrm{LP}=$ low pressure

LTS $=$ low temperature shift

LVGO = light vacuum gas oil

$\mathrm{M}=$ moisture

$\mathrm{MAF}=$ moisture and ash free

MDEA = methyl diethanolamine

MEA $=$ monoethanolamine

MON $=$ motor octane number

$\mathrm{NBP}=$ normal boiling point

PERC $=$ Pittsburgh Energy Research Center

$\mathrm{POC}=$ proof of concept

$\mathrm{POX}=$ partial oxidation

PSA $=$ pressure swing absorption

$\mathrm{PZ}=$ piperazine

$\mathrm{RFM}=$ reformate

$\mathrm{RON}=$ research octane number

ROSE-SR = Residual Oil Supercritical

Extraction-Solids Rejection

$\mathrm{SMR}=$ steam methane reforming 
$\mathrm{SRC}=$ solvent refined coal

$\mathrm{VM}=$ volatile materia

$\mathrm{ST}=$ steam turbine

\section{Reference}

[1] Williams RH, Larson ED. A comparison of direct and indirect liquefaction technologies for making fluid fuels from coal. Energy Sustain. Dev. 2003; 7(4):103-29.

[2] Jiang Y, Bhattacharyya D. Plant-wide modeling of an indirect coal-biomass to liquids (CBTL) plant with $\mathrm{CO}_{2}$ capture and storage (CCS). Int J Greenhouse Gas Control 2014; 31:1-15.

[3] Jiang Y, Bhattacharyya D. Modeling and analysis of an indirect coal biomass to liquids plant integrated with a combined cycle plant and $\mathrm{CO}_{2}$ capture and storage. Energy Fuels 2015; 29:543451.

[4] Jiang Y, Bhattacharyya D. Techno-economic analysis of a novel indirect coal-biomass to liquids plant integrated with a combined cycle plant and $\mathrm{CO}_{2}$ capture and storage. Ind Eng Chem Res 2016; 55:1677-89.

[5] Kieffer M, Brown T, Brown R. Flex fuel polygeneration: Integrating renewable natural gas into Fischer-Tropsch synthesis. Appl Energy 2016; 170:208-218.

[6] Dry ME. The Fischer-Tropsch process: 1950-2000. Catal Today 2002; 71: 227-41.

[7] Vasireddy S, Morreale B, Cugini A, Song C, Spivey JJ. Clean liquid fuels from direct coal liquefaction: chemistry catalysis technological status and challenges. Energy Environ Sci 2011; 4:311-45.

[8] Shui H, Cai Z, Xu C. Recent advances in direct coal liquefaction. Energies 2010; 3:155-70.

[9] Mochida I, Okuma O, Yoon S. Chemicals from Direct Coal Liquefaction. Chem Rev 2014; 114(3): 1637-72.

[10] Squirs A. Reaction paths in donor solvent coal liquefaction. Appl Energy 1978; 4(3): 161-185.

[11] Tchapda AH, Pisupati SV. A review of thermal co-conversion of coal and biomass/waste. Energies 2014; 7:1098-148.

[12] Chen Q, Rao K, Samuelsen S. Coproduction of transportation fuels in advanced IGCCs via coal and biomass mixtures. Appl Energy 2015; 157: 851-860.

[13] Srirangan K, Akawi L, Moo-Yang M, Chou C. Towards sustainable production of clean energy carriers from biomass resources. Appl Energy 2012; 100: 172-186.

[14] Stamford L, Azapagic A. Life cycle environmental impacts of UK shale gas. Appl Energy 2014; 134: 506-518. 
[15] Schakel W, Meerman H, Talaei A, Ramirez A, Faaij A. Comparative life cycle assessment of biomass co-firing plants with carbon capture and storage. Appl Energy 2014; 131: 441-467.

[16] Wang J, McNeel J. Assessments of Coal/Biomass to Liquid Fuels in West Virginia, Biomaterials and Wood Utilization Research Center, West Virginia University, July 10, 2009.

[17] Hartley D. Modeling and optimization of woody biomass harvest and logistics in the Northeastern United States. PhD Dissertation, West Virginia University: Morgantown, West Virginia, USA, 2014.

[18] Baliban RC, Elia JA, Floudas CA, Optimization framework for the simultaneous process synthesis, heat and power integration of a thermochemical hybrid biomass, coal and natural gas facility. Comput Chem Eng 2011; 35:1647-90.

[19] Liu G, Larson E, Williams R, Guo X. Gasoline from coal and/or biomass with $\mathrm{CO}_{2}$ capture and storage. 1. Process designs and performance analysis. Energy Fuels 2015; 29(3):1830-44.

[20] Baseline Technical and Economic Assessment of a Commercial Scale Fischer-Tropsch Liquids Facility, National Energy Technology Laboratory, DOE/NETL- 2007-1260, April 2007.

[21] Comolli AG, Lee LK, Pradhan VR, Stalzer TH, Harris EC, Mountainland DM et al. Direct Liquefaction Proof-of-Concept Facility, Technical Progress Report POC Run 01, Contract No. AC22-92PC92148, Hydrocarbon Research Inc., 1995.

[22] Gearhart JA, Nelson SR. ROSE process offers energy savings for solvent extraction. In: Proceedings of the 5th Industrial Energy Technology Conference Volume II, Houston, TX, 1983.

[23] Debyshire FJ. Varghese P, Whitehurst D.D. Integration of short-contact-time liquefaction and critical solvent deashing with gasification through methanol-to gasoline. Patent US4440622, 1984.

[24] Vaezi M, Passandideh-Fard M, Moghiman M, Charmchi M. Gasification of heavy fuel oils: a thermochemical equilibrium approach. Fuel 2011; 90: 878-85.

[25] Najjar MS, Gates WC. Partial oxidation of ash-containing solid carbonaceous and/or liquid hydrocarbonaceous fuel. Patent US4971601 A, 1990.

[26] Koseoglu OR. Process for the gasification of heavy residual oil with particulate coke from a delayed coking unit. Patent EP2737031 A1, 2014.

[27] Gasification of residual material from coal liquefaction, Final Report, Texaco Inc., Montebello Research Laboratory; 1984.

[28] Robin AM. Gasification of residual material from coal liquefaction, Quarterly Report, Texaco Inc., Montebello Research Laboratory, 1977.

[29] Bechtel and Amoco. Direct coal liquefaction baseline design and system analysis, Task III topical report: cost estimates and economics of the baseline and options, DEAC22-90PC89857, Pittsburgh, PA, September 1992. 
[30] Nagaoka K, Sato K, Nishiguchi H, Takita Y, Influence of support on catalytic behavior of nickel catalysts in oxidative steam prereforming of n-butane for fuel cell applications. Appl Catal A 2007; 327: 139-46.

[31] Yang JI, Ryu JH, Lee KY, Jung NJ, Park JC, Chun DH et al. Combined pre-reformer/reformer system utilizing monolith catalysts for hydrogen production. Int J Hydrogen Energy 2011; 36: 88506.

[32] Christensen TS. Adiabatic prereforming of hydrocarbons - an important step in syngas production. Appl Catal A Gen 1996; 138: 285-309.

[33] Stiller AH, Dadyburjor DB, Wann J, Tian D, Zondlo JW, Co-processing of agricultural and biomass waste with coal. Fuel Process Technol 1996; 49:167-75.

[34] Rafiqul I, Lugang B, Yan Y, Li T. Study on co-liquefaction of coal and bagasse by factorial experiment design method. Fuel Process Technol 2000; 68: 3-12.

[35] Comolli AG, Ganguli P, Stalzer RH, Lee TLK, Zhou P, The direct liquefaction co-processing of coal, oil, plastics, MSW and biomass. Trenton, NJ: ACS Preprints, Hydrocarbon Research Inc.; 1994, p. 300-5.

[36] Shui H, Shan C, Cai Z, Wang Z, Lei Z, Ren S et al. Co-liquefaction behavior of a sub-bituminous coal and sawdust. Energy 2011; 36(11): 6645-50.

[37] Coughlin RW, Davoudzadeh F. Coliquefaction of lignin and bituminous coal. Fuel 1986; 65: 95106.

[38] Anderson LL, Tuntawiro W. Coliquefaction of Coal and Polymers to Liquid Fuels. Amer Chem Soc Div Fuel Chem Preprints 1993; 38(4): 810-5.

[39] Ai J. Preliminary study on hydro-liquefaction kinetics of Shenhua coal macerals and coliquefaction of macerals, Master thesis, China Coal Research Institute, 2007.

[40] Onozki M, Namiki Y, Ishibashi H, Takagi T, Kobayashi M, Morooka S. Steady-state thermal behavior of coal liquefaction reactors based on NEDOL process. Energy Fuels 2000; 14: 355-63.

[41] Shan X, Li K, Zhang X, Jiang H, Weng H. Reaction kinetics study on the heating stage of the Shenhua direct coal liquefaction process. Energy Fuels 2015; 29: 2244-9.

[42] Jiang H, Wang X, Shan Z, Li K, Zhang X, Cao X, Weng H. Isothermal stage kinetics of direct coal liquefaction for Shenhua Shendong bituminous coal. Energy Fuels 2015; 29: 7526-31.

[43] Itoh H, Hiraide M, Kidoguchi A, Onozaki M, Ishibashi H, Namiki Y et al. Simulator for coal liquefaction based on the NEDOL process. Ind Eng Chem Res 2001; 40: 210-7.

[44] Tola V, Pettinau A. Power generation plants with carbon capture and storage: A techno-economic comparison between coal combustion and gasification technologies. Appl Energy 2014; 113: 14611474. 
[45] Kohl A, Nielsen R. Gas Purification. 5th ed. Houston, TX: Gulf Professional Publishing; 1997.

[46] Cost and Performance Baseline for Fossil Energy Plant Volumn 1: Bituminous Coal and Natural Gas to Electricity, National Energy Technology Laboratory, DOE/NETL -2010/1397, November 2010.

[47] Liu G, Williams RH, Larson E, Kreutz T. Making Fischer-Tropsch fuels and electricity from coal and biomass: performance and cost analysis. Energy Fuels 2011; 25: 415-37.

[48] Bhattacharyya D, Turton R, Zitney SE. Steady-state simulation and optimization of an integrated gasification combined cycle power plant with $\mathrm{CO}_{2}$ capture. Ind Eng Chem Res 2011; 50: 1674-90.

[49] Bain RL. Material and Energy Balances for Methanol from Biomass Using Biomass Gasifiers, National Renewable Energy Laboratory, DE-AC36-83CH10093, 1992.

[50] Bullin K, Krouskop P. Composition variety complicates processing plans for US shale gas. Oil and Gas Journal March 92009.

[51] Bechtel and Amoco, Direct coal liquefaction baseline design and system analysis, Quarterly Report, DEAC2290PC89857, September 1990.

[52] Cheng Z, Huang Z, Yang T, Liu J, Ge H, Jiang L et al. Modeling on scale-up of an ebullated-bed reactor for the hydroprocessing of vacuum residuum. Catal Today 2014; 220-222: 228-36.

[53] Robinson KK. Reaction engineering of direct coal liquefaction. Energies 2009; 2: 976-1006.

[54] Valente AM, Cronauer DC. Analyses of Illinois No.6 coal liquefaction results generated in the Wilsonville, Alabama Unit. Energy Fuels 2005; 19: 489-98.

[55] Bechtel and Amoco, Direct coal liquefaction baseline design and system analysis, Quarterly Report, DEAC2290PC89857, September 1990.

[56] Behrendt F, Neubauer Y, Oevermann M, Wilmes B, Zobel N. Direct Liquefaction of Biomass. Chem Eng Technol 2008; 31: 667-77.

[57] Stevens DJ. An overview of biomass thermochemical liquefaction research sponsored by the U.S. Department of Energy. Amer Chem Soc Div Fuel Chem Prepr 1987; 32(2): 223-8.

[58] Sofer SS, Zaborsky OR. Biomass conversion processes for energy and fuels. New York: Springer Science \& Business Media; 2012.

[59] White DH, Wolf D, Zhao Y. Biomass liquefaction utilizing extruder-feeder reactor systems. Amer Chem Soc Div Fuel Chem Prepr 1987; 32(2): 106-16.

[60] Elliott DC. Process development for biomass liquefaction. Amer Chem Soc Div Fuel Chem Prepr 1980; 25(4): 257-63.

[61] Givens EN, Kang D. Coal liquefaction process with enhanced process solvent. Patent US4461694, 1984.

[62] Baldwin RA, Bills JL, Processes for the production of deashed coal. Patent US4119523, 1978. 
[63] Fahim MA, Al-Sahhaf TA, Elkilani A. Fundamentals of Petroleum Refining. 1st ed. Oxford, UK: Elsevier Science; 2010.

[64] Rhodes DE. Process for improving soluble coal yield in a coal deashing process. Patent US4225420, 1980.

[65] Morris SM, Foster EP. The SRC-I Coal Refining Demonstration Plant. International Coal Refining Company, http://www.fischer-tropsch.org; 1983 [accessed 16.05.31].

[66] Thorogood RM. Solvent refined coal reactor quench system. Patent US4414094 A, 1983.

[67] Shih CT. Experimental hydrodynamic study of the slurry distribution in a vertical slurry heat exchanger, PhD dissertation, University of Nevada, Las Vegas; 1995.

[68] Shinn JH. From coal to single-stage and two-stage products: a reactive model of coal structure. Fuel 1984; 63: 1187-95.

[69] Zhou P, Rao SN, Assessment of coal liquids as refinery feedstocks, Prepared for DOE Pittsburgh Energy Technology Center, February 1992.

[70] Bechtel, Baseline Design/Economics for Advanced Fischer-Tropsch Technology, Quarterly Report, DE-AC22-91PC90027, January - March 1993.

[71] Gary JH, Handwerk GE. Petroleum Refining Technology and Economics. 4th ed. New York: Marcel Dekker Inc.; 2001.

[72] Smith MR, Hubbard DA, Yang CC. Logic, technology and effect of coal liquefaction condition on final up-graded product slate. In: Proceedings of the 9th Annual International Conference on Coal Gasification, Liquefaction, and Conversion to Electricity, 1982.

[73] Albahri TA, Riazi MR, Alqattan AA. Octane number and aniline point of petroleum fuels. Amer Chem Soc Div Fuel Chem Prepr 2002; 47(2): 710-1.

[74] Jenkins GI. Journal of Institute of Petroleum 1968; 54: 14.

[75] Wu X, Shu G, Li K, Xie S. Technology and Engineering of Direct Coal Liquefaction Process. Beijing: Science Press; 2015.

[76] Molburg JC, Doctor RD. Hydrogen from steam-methane reforming with $\mathrm{CO}_{2}$ capture. In: Proceedings of the 20th Annual International Pittsburgh Coal Conference, Pittsburgh, USA, September 15-19, 2003.

[77] Robin AM. Hydrogen production from coal liquefaction residues, Final Report, Texaco Inc., Montebello Research Laboratory, December 1976.

[78] Penner SS. Assessment of long-term research needs for coal-liquefaction technologies, University of California, San Diego, March 1980.

[79] Gao J. Coal liquefaction residue and coal water slurry combined gasification nozzle and application thereof. Chinese Patent CN102268300 B, 2014. 
[80] Austgen DM, Rochelle GT, Chen C. Model of vapor-liquid equilibria for aqueous acid gasalkanolamine systems 2 representation of $\mathrm{H}_{2} \mathrm{~S}$ and $\mathrm{CO}_{2}$ solubility in Aqueous MDEA and $\mathrm{CO}_{2}$ solubility in aqueous mixtures of MDEA with MEA and DEA. Ind Eng Chem Res 1991; 30: 543555.

[81] Rinker EB, Ashour SS, Sandall OC. Experimental absorption rate measurements and reaction kinetics for $\mathrm{H} 2 \mathrm{~S}$ and $\mathrm{CO} 2$ in aqueous DEA, MDEA and blends of DEA and MDEA, GPA Research Report, No. 159, 1997.

[82] Clean coal technologies in Japan, New Energy and Industrial Technology Development Organization, Kawasaki, Japan, 2006.

[83] Review of worldwide coal to liquids $R, D \& D$ activities and the need for further initiatives within Europe, IEA Coal Research Ltd., RFC2-CT-2008-00006, http://www.iea-coal.org.uk; June 2009 [accessed 05.01.16].

[84] Turton R, Bailie RC, Whiting WB, Shaeiwitz JA, Bhattacharyya D. Analysis, Synthesis, and Design of Chemical Process. 4th ed. Boston: Pearson Education; 2012.

[85] Bauman RF, Maa PS, Direct coal liquefaction process, Patent CN104937077A, 2014.

[86] Ji S, Bagajewicz M. Design of crude distillation plants with vacuum units I targeting. Ind Eng Chem Res 2002; 41: 6094-6099.

[87] Bagajewicz M, Ji S. Rigorous procedure for the design of conventional atmospheric crude fractionation units I targeting. Ind Eng Chem Res 2001; 40: 617-626. 